Pedro Henrique da Silva Santos Salerno

Secretários da Fazenda e do Planejamento influenciam o orçamento? Evidências para os estados brasileiros

São Paulo 
Prof. Dr. Vahan Agopyan

Reitor da Universidade de São Paulo

Prof. Dr. Fábio Frezatti

Diretor da Faculdade de Economia, Administração e Contabilidade

Prof. Dr. José Carlos de Souza Santos

Chefe do Departamento de Economia

Prof Dr. Ariaster Baumgratz Chimeli

Coordenador do Programa de Pós-Graduação em Economia 
Pedro Henrique da Silva Santos Salerno

\title{
Secretários da Fazenda e do Planejamento influenciam o orçamento? Evidências para os estados brasileiros
}

\begin{abstract}
Dissertação apresentada ao Programa de PósGraduação em Economia do Departamento de Economia da Faculdade de Economia, Administração e Contabilidade da Universidade de São Paulo, como requisito parcial para a obtenção do título de Mestre em Ciências.
\end{abstract}

Orientador: Profa. Dra. Fabiana Fontes Rocha

Versão Corrigida

São Paulo 
Salerno, Pedro Henrique da Silva Santos

Secretários da Fazenda e do Planejamento influenciam o orçamento? Evidências para os estados brasileiros / Pedro Henrique da Silva Santos Salerno. - São Paulo, 2021.

$53 p$.

Dissertação (Mestrado) - Universidade de São Paulo, 2021. Orientador: Profa. Dra. Fabiana Fontes Rocha.

1. Finanças Públicas. 2. Estados Brasileiros. 3. Orçamento. 4. Secretários. 5. Erros de Previsão. I. Universidade de São Paulo. Faculdade de Economia, Administração e Contabilidade. II. Título. 
Pedro Henrique da Silva Santos Salerno

\section{Secretários da Fazenda e do Planejamento influenciam o orçamento? Evidências para os estados brasileiros}

Dissertação apresentada ao Programa de PósGraduação em Economia do Departamento de Economia da Faculdade de Economia, Administração e Contabilidade da Universidade de São Paulo, como requisito parcial para a obtenção do título de Mestre em Ciências.

Profa. Dra. Fabiana Fontes Rocha IPE-USP

Profa. Dra. Ana Carolina Giuberti UFES

Prof. Dr. Pedro Henrique Thibes Forquesato IPE-USP

Prof. Dr. Sérgio Naruhiko Sakurai FEA-RP/USP

São Paulo 
Aos meus pais. 


\section{Agradecimentos}

Dou graças a Deus, meu Senhor. Agradeço minha família, pelo apoio e amor irrestritos. Agradeço à professora Fabiana por toda a orientação, conselhos e suporte nestes últimos anos, e por ter sido minha companheira em minhas vitórias e (muitas) dificuldades. Aos meus amigos do mestrado, especialmente Leal, Zé e Gabriel, também estrangeiros à São Paulo, que trouxeram alegria, apoio e amizade aos dias mais cinzas. Agradeço à Igreja Presbiteriana do Butantã, que me acolheu em São Paulo, e todos os queridos irmãos e amigos que foram meu suporte nesta fase. Também agradeço os demais professores e funcionários da FEA, e por todo o apoio financeiro concedido pela FIPE e pelo CNPq. 


\section{Resumo}

Este trabalho conversa com duas literaturas distintas sobre os determinantes dos resultados fiscais. A primeira trata do efeito dos erros de previsão presentes no processo orçamentário sobre o resultado fiscal, considerando a relevância dos agentes políticos sobre estes. A segunda literatura abordada a importância das características individuais dos ministros/secretários das finanças para o desempenho fiscal. Utilizando uma base de dados em painel dos 26 estados brasileiros e do Distrito Federal no período de 1995 a 2018, observa-se que $25 \%$ e $50 \%$ da subestimação de receita se manifesta como melhora do resultado fiscal. Não se encontra efeito significativo da superestimação da receita como piora do resultado fiscal. Com uso de dados inéditos dos secretários estaduais brasileiros, encontra-se evidência de que Secretários da Fazenda mais experientes no cargo influenciam negativamente os balanços fiscais. Os Secretários do Planejamento afetam os resultados fiscais somente através dos erros de previsão. Secretários mais experientes, com doutorado e com formação em finanças ou engenharia estão associados com melhores resultados fiscais, através da subestimação da receita. Tais observações são importantes para entender qual é a responsabilidade dos secretários incumbidos pelo orçamento sobre a trajetória fiscal dos estados brasileiros.

Codificação JEL: C33, H30, H71, H72

Palavras-chave: Deficit Fiscal, Erros de Previsão, Estados Brasileiros, Secretários de finanças 


\begin{abstract}
This paper contributes to two distinct branches of literature about the determinants of fiscal balances. The first one discusses the role of budgeting forecasting errors on fiscal deficits. The second one addresses the role of the individual characteristics of finance ministers/subnational ministers for fiscal performance. Using a panel database of 26 Brazilian states and the Federal District between 1995 and 2018, we observe that between $25 \%$ and $50 \%$ of tax revenue underestimation manifests itself in reducing fiscal deficits. There is no significant effect of the overestimation of tax revenue increasing fiscal deficits. Based on an original database concerning the subnational ministers we find out that more experienced 'finance' secretary's influence negatively the fiscal balance. 'Planning"secretarý's influence the fiscal results only through the budgeting errors. Most experienced and educated 'planning' secretary's experience and academic are correlated to better fiscal results, through the sub estimation of tax revenue. Those results are relevant to understand what is the actual influence of secretaries responsible for the budget on the Brazilian states' fiscal path.
\end{abstract}

JEL Classification: C33, H30, H71, H72

Keywords: Fiscal deficits, Budgeting Errors, Brazilian States, Finance ministers 


\section{Lista de tabelas}

Tabela 1 - Erros de Previsão de Receita e Resultados Fiscais dos Estados Brasileiros, 1995-2018 . . . . . . . . . . . . . . . . . 11

Tabela 2 - Descrição e fonte das principais variáveis . . . . . . . . . . . . . . 12

Tabela 3 - Estatísticas Descritivas das principais variáveis . . . . . . . . . . 14

Tabela 4 - Estatísticas Descritivas das variáveis referentes aos Secretários . . . . . 18

Tabela 5 - Regressão do Erro de Previsão sobre o Resultado Fiscal. . . . . . . . . 22

Tabela 6 - Regressão da Erro de Previsão, segmentado entre super e subestimação, sobre o Resultado Fiscal . . . . . . . . . . . . . . . . . . . . 24

Tabela 7 - Teste formal da simetria do efeito do Erro de Previsão sobre o Resultado Fiscal . . . . . . . . . . . . . . . . . . . 24

Tabela 8 - Regressão das características dos Secretários da Fazenda sobre o Resultado Fiscal . . . . . . . . . . . . . . . . . . . . . 27

Tabela 9 - Testes de Significância das características do Secretário da Fazenda sobre o Resultado Fiscal . . . . . . . . . . . . . . . . . . . . 28

Tabela 10 - Regressão do Erro de Previsão sobre o Resultado Fiscal . . . . . . . . . 29

Tabela 11 - Regressão do Erro de Previsão sobre o Resultado Fiscal . . . . . . . . . 30

Tabela 12 - Testes de Significância das características do Secretário do Planejamento sobre o Erro de Previsão . . . . . . . . . . . . . . . . . . . . . . . . . . 31

Tabela 13 - Observações de Secretários - Variáveis Principais . . . . . . . . . . . . 40

Tabela 14 - Observações de Secretários - Nível de Instrução . . . . . . . . . . . . 41

Tabela 15 - Observações de Secretários do Planejamento - Curso Superior ... . 42

Tabela 16 - Observações de Secretários da Fazenda - Curso Superior . . . . . . . . . 43

Tabela 17 - Matriz de correlação entre Resultado Fiscal e características do Secretário da Fazenda . . . . . . . . . . . . . . . . . . . . . 44 45

Tabela 18 - Matriz de correlação entre Erro e características do Secretário do Planejamento . . . . . . . . . . . . . . . . . 4 46

Tabela 19 - Teste t sobre a contratação de Secretários da Fazenda após períodos de recessão econômica. . . . . . . . . . . . . . . . . . . . . 47 47

Tabela 20 - Regressão do Resultado Fiscal explicado pelo Erro de Previsão, incluindo variável binária de ideologia do governador . . . . . . . . . . . . . . . . 48

Tabela 21 - Regressão das características dos Secretários da Fazenda, exclusive gênero, sobre o Resultado Fiscal . . . . . . . . . . . . . . . . . . . 49

Tabela 22 - Regressão das características dos Secretários da Fazenda sobre o Resultado Fiscal, excluindo o Erro de Previsão das variáveis explicativas . . 50 
Tabela 23 - Regressão das características dos Secretários da Fazenda sobre o Resultado Fiscal, incluindo variáveis binárias de ideologia do governador e do secretário . . . . . . . . . . . . . . . . . . . 51

Tabela 24 - Regressão das características dos Secretários do Planejamento, exclusive gênero, sobre o Erro de Previsão . . . . . . . . . . . . . . . . . . . . 52

Tabela 25 - Regressão das características dos Secretários do Planejamento, inclusive binárias de ideologia do Secretário e do Governador, sobre o Erro de Previsão . . . . . . . . . . . . . . . . . . . . . 53 


\section{Sumário}

INTRODUÇÃO $\ldots \ldots \ldots \ldots \ldots \ldots \ldots \ldots$

2 CONTEXTO INSTITUCIONAL $\ldots \ldots \ldots \ldots \ldots$

3 ANÁLISE EMPÍRICA $\ldots \ldots \ldots \ldots \ldots \ldots$

$3.1 \quad$ Especificação dos modelos $\ldots \ldots \ldots \ldots \ldots$

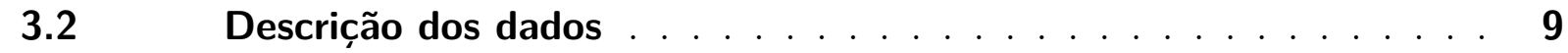

3.2.1 Resultado Fiscal e Erros de Previsão . . . . . . . . . . . . . . . . . 9

3.2.2 Variáveis de controle . . . . . . . . . . . . . . . . . 10

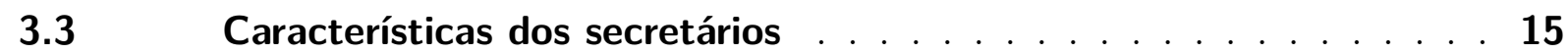

3.3.1 A construção da base de dados . . . . . . . . . . . . . . 15

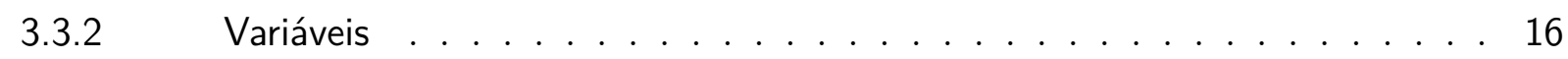

4 ERRO DE PREVISÃO E RESULTADO FISCAL $\ldots \ldots \ldots \ldots$

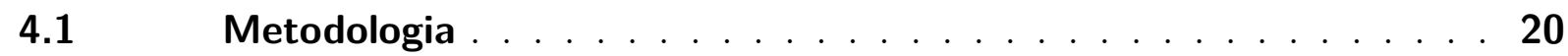

$4.2 \quad$ Resultados . . . . . . . . . . . . . . . . . . 22

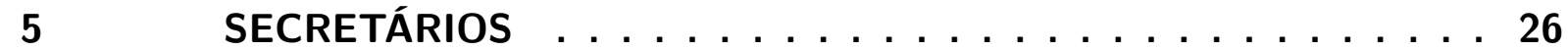

5.1 Secretários da Fazenda e Resultado Fiscal . . . . . . . . . 26

5.2 Secretários do Planejamento e Erro de Previsão . . . . . . . . . . . 28

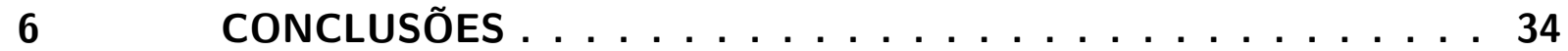

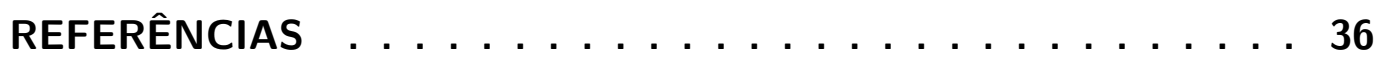

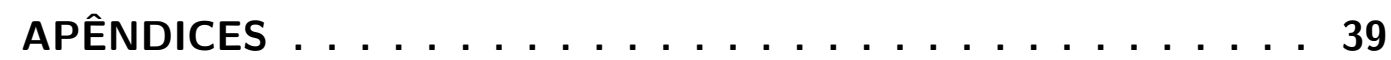

APÊNDICE A - OBSERVAÇÕES DE SECRETÁRIOS . . . . 39

APÊNDICE B - MATRIZES DE CORRELAÇÃO . . . . . . . . 44

APÊNDICE C - TESTES E ESTIMAÇÕES ALTERNATIVAS $\ldots 47$ 


\section{Introdução}

A maior parte da literatura sobre os determinantes dos resultados fiscais foca no papel das regras e instituições fiscais (Debrun et al. (2008)), dos procedimentos eleitorais (Feld e Kirchgässner (2001)), dos determinantes políticos (Perotti e Kontopoulos (2002); Volkerink e Haan (2001)) ou dos procedimentos orçamentários (Alesina e Perotti (1996); Hallerberg, Strauch e Hagen (2009)).

Ao longo do tempo essa literatura foi expandida em duas direções independentes, mas que podem ser usadas de forma complementar para avaliar o caso brasileiro.

A primeira trata especificamente do papel desempenhado pelo erro de previsão das receitas no orçamento. Alesina et al. (1999) sugerem que políticos podem deliberadamente superestimar as receitas a fim de gerar déficits e assim alcançar seus próprios objetivos. Isto é possível porque os déficits observados podem, em última instância, podem ser justificados pelas dificuldades técnicas envolvidas na previsão das receitas futuras. Por outro, como observa van der Ploeg (2010), a subestimação intencional da base tributária pode conter os impulsos gastadores dos ministros das finanças e consequentemente reduzir a dívida.

As evidências empíricas são diversas. Goeminne, Geys e Smolders (2008), ao avaliarem empiricamente os municípios belgas, mostram que a previsão de receitas pode ser usada como instrumento para evitar déficits excessivos. Em um contexto de atrito entre diversos grupos políticos, cada um deles lutando por uma parte do orçamento a fim de manter suas bases de apoio, o viés otimista na projeção da receita aparece como uma forma de acomodar as tensões envolvidas nas diferentes demandas. Couture e Imbeau (2009) associam os erros de previsão das províncias canadenses a períodos de incerteza econômica, sendo os períodos bons marcados por tendências à subestimação. Anos eleitorais são marcados por maior superestimação, governos ideologicamente à direita cometem erros menores e leis que buscam disciplina fiscal levam a previsões mais conservadoras. Em contraponto, Bischoff e Gohout (2010) mostram maior viés otimista das previsões de receitas dos estados alemães em momentos de piores resultados macroeconômicos e/ou baixa popularidade dos governantes. Chatagny e Soguel (2011) encontram evidência que subestimar as receitas reduz os déficits fiscais dos cantões suíços através de reduções nas despesas. Finalmente, Chatagny (2013) mostra que ministros de finanças ideologicamente mais à esquerda produzem, contrariamente ao esperado, previsões mais conservadoras. Como o déficit observado pode ser usado como sinalizador de competência, eles se esforçam para conduzir de forma responsável a política fiscal com o propósito de ganhar a credibilidade que eles não têm a priori. A adoção de regras fiscais não afeta o erro de previsão em si, mas reduz o efeito da ideologia do ministro sobre os 
erros de previsão. Como consequência, a importância de sinalizar credibilidade é menor em um contexto de menor discricionariedade da política fiscal.

Esta dissertação tem então como primeiro objetivo avaliar o papel desempenhado pelos erros de previsão de receita sobre os resultados fiscais dos estados brasileiros no período 1994-2018, contribuindo para a literatura empírica mais recente que não aceita os resultados teóricos como dados.

A segunda trata da importância das características individuais do ministro das finanças para o resultado fiscal.

A teoria de finanças públicas tradicional parte do pressuposto de que a responsabilidade pelo orçamento é de todos os ministros. Isto levaria a um problema de recursos comuns (Buchanan (1960), cap. 11) uma vez que neste contexto um orçamento público saudável tem características de bem público. Se o orçamento é fixado de forma descentralizada, ministros gastadores escolhem seus gastos de forma independente, resultando num orçamento grande demais (Von Hagen e Harden (1995)). No entanto, o ministro das finanças tem seu sucesso e prestígio atrelados à condução da política fiscal e dessa forma, entre todos os ministros, é o que o tem o maior interesse em manter as finanças públicas saudáveis e a dívida pública numa trajetória sustentável. Ele atuaria assim como um contrapeso aos demais ministros, podendo ser definido como o especialista fiscal do governo. No entanto, como observado por Besley (2005, p. 58), 'modern political economy has tended to focus only on the incentives faced by politicians for good or bad behavior, while neglecting the importance of selection. But no society can run effective public institutions while ignoring the quality of who is recruited to public office and what they stand for.'

Esta dissertação tem então como segundo objetivo entender a possível influência das características pessoais e profissionais dos secretários da Fazenda e do Planejamento sobre a condução da política fiscal. Desta forma, dialoga também com a literatura que analisa a relevância das características dos tomadores de decisão sobre diferentes resultados como o crescimento econômico (Dreher et al. (2009)); a condução da política monetária (Farvaque, Stanek e Hammadou (2011), Göhlmann e Vaubel (2007)); a administração de empresas (Bertrand e Schoar (2003)); corrupção e patronagem (Brollo e Troiano (2016)) e que só mais recentemente passou a tratar da condução da política fiscal (Jochimsen e Thomasius (2014), Moessinger (2014)).

Jochimsen e Thomasius (2014) encontram evidências de que ministros subnacionais com experiência profissional em finanças (independentemente da formação acadêmica) e que passam mais tempo no cargo são relativamente mais fortes e se mostram correlacionados a déficits menores. Moessinger (2014), por sua vez, numa análise para ministros das finanças nacionais na Europa, testa a importância das características individuais sobre o endividamento. Encontra evidências de que a experiência do ministro das finanças impacta negativamente a razão dívida/PIB e o crescimento da dívida diminui (ou a redução da 
dívida aumenta) à medida que o ministro passa mais tempo no cargo. Este efeito é atenuado em épocas de maior crescimento econômico, corroborando a ideia de que um ministro das finanças 'forte' e 'prudente' pode ser mais importante em épocas de dificuldade econômica. Ideologia partidária e a formação acadêmica são pouco relevantes, mas em momentos de crise econômica aumenta a probabilidade de economistas serem escolhidos para o cargo.

Esta dissertação inova ao descrever pela primeira vez as características pessoais dos secretários estaduais da Fazenda e do Planejamento no Brasil e usá-las como determinantes dos resultados fiscais. Além disso, se diferencia ao analisar um contexto institucional diferente.

Na literatura internacional, estuda-se o único finance minister presente no gabinete quando a análise trata de países ou o único subnational finance minister quando a análise envolve estados. No caso brasileiro, contudo, a prática mais comum é distinguir as tradicionais responsabilidades quanto à condução da política fiscal entre a pasta da Fazenda e a pasta do Planejamento.

Ainda que quantidade de pastas e suas atribuições sejam heterogêneas, tanto entre os diferentes estados quanto ao longo do tempo, a organização mais usual diferencia a pasta da Fazenda, responsável pelos saldos fiscais e a efetiva arrecadação tributária, da pasta frequentemente chamada do Planejamento, responsável pela elaboração e gestão da execução do orçamento. Desta forma, neste trabalho assume-se que os Secretários da Fazenda são responsáveis pela execução orçamentária dos anos fiscais em que estão no cargo e que o efeito de curto prazo do Secretário de Planejamento se dá somente através da sua responsabilidade sobre as peças orçamentárias feitas no ano anterior, na fase de elaboração do orçamento.

Se o Secretário do Planejamento é responsável pela elaboração das peças orçamentárias e pelas previsões nelas contidas, ele pode agir de forma a usar os erros de previsão como um instrumento oculto de política fiscal, especialmente em um contexto de regras fiscais rígidas e gastos obrigatórios elevados. Assim, as características individuais de ambos os secretários podem afetar o resultado fiscal. No caso dos secretários da Fazenda diretamente, como é observado no restante do mundo. No caso dos secretários do Planejamento indiretamente, através dos erros de previsão do orçamento.

Este trabalho está organizado em cinco seções, além desta Introdução. A segunda seção apresenta o contexto institucional do processo orçamentário dos estados brasileiros, especialmente considerando a divisão de responsabilidades entre as pastas da Fazenda e do Planejamento. A terceira seção apresenta a base de dados em painel referentes aos Secretários da Fazenda e Planejamento dos estados brasileiros, além das demais variáveis de interesse e controle. A quarta seção apresenta os resultados empíricos da estimação do efeito do erro de previsão e sobre o resultado fiscal, enquanto a quinta seção avalia o papel dos Secretários da Fazenda sobre o Resultado Fiscal e dos Secretários do Planejamento 
sobre o Erro de Previsão. Por fim, a sexta seção reúne as considerações finais e conclusões. 


\section{Contexto Institucional}

O modelo atual de processo orçamentário do Brasil advém da Constituição Federal de 1988 (artigos 165 a 169). Esta estabelece o processo orçamentário, através de três instrumentos legais de responsabilidade do Poder Executivo, ligados de forma hierárquica: o Plano Plurianual (PPA), a Lei de Diretrizes Orçamentárias (LDO) e a Lei Orçamentária Anual (LOA) (BRASIL, 1988). A promulgação da Lei Complementar n. 101 de 2000, conhecida como Lei de Responsabilidade Fiscal (LRF) complementou o sistema com novas regras de resultado e de procedimento ${ }^{1}$, além de novas responsabilidades para os agentes envolvidos no orçamento.

As constituições estaduais e a Lei Orgânica do Distrito Federal seguem o estabelecido na Constituição e, assim, o processo orçamentário estadual geralmente segue o que foi estabelecido para a esfera federal. Podem existir, porém, pequenas variações no rito orçamentário entre unidades federativas; para uma avaliação detalhada da elaboração e execução dos orçamentos estaduais ver Leal (2020).

O Plano Plurianual ${ }^{2}$ é o instrumento de planejamento de médio e longo prazo e define as metas e diretrizes (em linhas gerais e amplas) de despesa do governo estadual. Seu projeto deve ser elaborado no primeiro ano de governo e sua duração é de quatro anos, de modo que é válido até o primeiro ano do governo sucessor.

A Lei de Diretrizes Orçamentárias estabelece objetivos e diretrizes legais para a elaboração do orçamento para o exercício financeiro subsequente, atuando como ligação entre o PPA e a LOA. A discussão anual da LDO permite que os parâmetros do orçamento e as prioridades na execução do gasto público sejam revistos e aprovados antes da discussão do orçamento em si (REZENDE, 2009). Como visto anteriormente, com a promulgação da LRF, a LDO passa a dispor sobre o equilíbrio entre receitas e despesas, as formas e critérios da limitação de empenho, a meta de superavit primário e o seu relacionamento com o montante da dívida e o limite à expansão de despesas obrigatórias de caráter continuado (BRASIL, 2000).

Por fim, a Lei Orçamentária Anual é a peça orçamentária que consolida o orçamento em si. Nesta, as receitas são estimadas e as despesas são fixadas em mesmo valor. A Lei

1 Na teoria de orçamento público, restrições de orçamento equilibrado (em que as receitas e as despesas se igualam em cada período) são exemplos de regras de resultado; estas se definem como objetivos numéricos estabelecidos anteriormente ao início do processo orçamentário. De diferente modo, regras de procedimento são as que definem os processos pelos quais as decisões orçamentárias são feitas. Estas regras definem a autoridade e a responsabilidade de cada agente envolvido no processo orçamentário, além do calendário e do fluxo de informação interno ao processo (SHAH, 2007).

2 Constitucionalmente, o PPA deve ser enviado pelo Governador até a Assembleia Legislativa estadual até 31 de Agosto do primeiro ano de mandato, enquanto a LDO deve ser enviada todos os anos até 15 de Abril. 
de Responsabilidade Fiscal, na Seção I do Capítulo III, trata da Previsão e Arrecadação da Receita, estabelecendo no Artigo 12 que que as previsões de receita observarão normas técnicas e legais, e considerarão os efeitos de I) alterações na legislação; II) variação no índice de preços; III) crescimento econômico e IV) qualquer outro fator relevante, além de serem acompanhadas de sua trajetória nos últimos três anos, a projeção para os dois anos seguintes e a metodologia de cálculo e premissas utilizadas.

Na prática, os autores observam que a exposição adequada, tanto da metodologia quanto das premissas e previsões macroeconômicas utilizadas como insumos, é rara entre os entes subnacionais ${ }^{3}$ (BRASIL, 2000).

As secretarias estaduais do Planejamento (e Orçamento) são usualmente responsáveis pela elaboração e monitoramento das três peças orçamentárias acima descritas. Observa-se então uma importante responsabilidade de médio e longo prazo da secretaria, a medida que os processos de formulação e avaliação das metas da administração pública se encontram sob esta pasta. Além disto, a incumbência de elaboração das LDOs e LOAs fazem com que também sejam atribuições desta secretaria o estabelecimento de premissas, metodologias e projeções econômicas a serem utilizadas como insumos do orçamento e de outros atos da gestão estadual.

Como ilustração da importância da burocracia orçamentária e da qualidade dos incumbentes da Secretaria do Planejamento, observamos em um abrangente questionário de 2011 enviado pela União às Secretarias de Planejamento estaduais indícios preocupantes ${ }^{4}$. Através destes questionários, do universo de 27 Unidades da Federação, 7 estados declararam não possuir metodologia para previsão de receitas; 11 declararam não possuir estrutura física e de recursos humanos para projetar as receitas do Estado; 4 estados admitiram não desenvolver cenários fiscais para a elaboração da LOA enquanto 9 declararam não atualizar as projeções do cenário fiscal após a sanção da LOA (PLANEJAMENTO, 2011).

O Projeto de Lei Orçamentária Anual (PLOA) deve ser encaminhada pelo Poder Executivo até o dia 31 de Agosto, começando assim a fase de apresentação de emendas e aprovação de responsabilidade do Poder Legislativo. Após a aprovação, encerra-se a fase legislativa e inicia-se efetivamente a fase de implementação do orçamento durante o ano fiscal de exercício, de responsabilidade do Poder Executivo.

3 A União, de outro modo, através da Secretaria do Tesouro Nacional, publica em seu 'Manual da Receita' o método de estimação dos tributos de sua competência. As previsões de receitas administradas pela Receita Federal, exceto as de natureza previdenciária, têm sua base metodológica no método incremental ou de indicadores, baseado nas diretrizes do Artigo 12 da LRF ((PIZA, 2016)). O próprio Manual, porém, esclarece que a metodologia deve variar de acordo com cada espécie de receita, possibilitando mesmo o desenvolvimento de novos modelos (FAZENDA, 2008).

4 A Secretaria de Orçamento Federal, adjunta ao Ministério do Planejamento, Orçamento e Gestão, resolveu no ano de 2011 pela execução de um 'Diagnóstico da Área Orçamentária dos Estados Brasileiros', com intento de compreender o desenvolvimento da burocracia orçamentária dos governos estaduais, e é a fonte dos dados aqui apontados (PLANEJAMENTO, 2011) 
Habitualmente, as secretarias estaduais da Fazenda possuem como principal atribuição a gestão das políticas tributária e fiscal do Estado, responsabilizando-se pelos sistemas financeiro e contábil do Tesouro.

Dentre as principais responsabilidades da pasta estão a arrecadação e fiscalização dos tributos de competência estadual, assim como o monitoramento da estrutura de despesas estaduais e a contabilidade derivada destas receitas e despesas.

Observa-se, deste modo, que a participação dos Secretários da Fazenda no rito orçamentário manifesta-se essencialmente na fase de implementação do orçamento pelo Executivo, que ocorre durante o ano fiscal; conjectura-se que a Secretaria da Fazenda não teria responsabilidade sobre estrita sobre os desvios de previsão contidas no orçamento aprovado, mas sim por possíveis 'desvios de execução' e revisões feitas ao orçamento durante sua execução. 


\section{Análise Empírica}

\subsection{Especificação dos modelos}

Como estabelecido na introdução serão avaliados os efeitos dos erros de previsão e das características dos secretários da Fazenda sobre o resultado fiscal. Como assume-se os secretários do Planejamento só podem afetar o resultado fiscal em curto prazo através dos erros de previsão, será avaliado ainda o papel das características dos secretários do Planejamento sobre os erros de previsão.

Desta forma, serão estimados dois modelos principais.

O primeiro que procura avaliar os determinantes do resultado fiscal é um modelo dinâmico em que o resultado fiscal de um período é influenciado pela primeira defasagem do resultado fiscal, além de fatores correntes.

Seguindo Jochimsen e Thomasius (2014), o modelo dinâmico assume a forma descrita na equação 3.1 :

$$
\text { Resultado }_{i t}=\alpha+\beta \text { Erro }_{i t}+\gamma \text { Resultado }_{i t-1}+\mu P_{i t}+\theta X_{i t}+\eta_{i}+\tau_{t}+\epsilon_{i t}
$$

, em que $\mathrm{i}=1, \ldots, 27$ identifica as unidades federativas brasileiras e $\mathrm{t}=1995, \ldots, 2018$

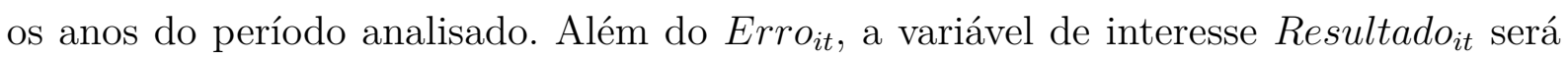
explicada pelo resultado fiscal defasado um período (devido ao impacto que resultados fiscais negativos podem ter sobre o esforço de arrecadação), além de matriz de variáveis de controle $P_{i t}$ e da matriz de variáveis referentes aos secretários da Fazenda $X_{i t}$. Além disso, se insere efeitos fixos de estado $\eta_{i}$ e de ano $\tau_{t}$.

O segundo é o modelo que explica os erros de previsão:

A equação de estimação do Erro pode ser formalizada como na equação 3.2 abaixo, em que $\mathrm{i}=1, \ldots, 27$ identifica as unidades federativas brasileiras e $\mathrm{t}=1995, \ldots, 2018$ os anos do período analisado. Nesta, utiliza-se a matriz de características dos Secretários do Planejamento defasada em um ano $\left(Z_{i t-1}\right)$ :

$$
\text { Erro }_{i t}=\alpha+\theta Z_{i t-1}+\mu P_{i t}+\eta_{i}+\tau_{t}+\epsilon_{i t}
$$

Assume-se que o termo de erro $\epsilon_{i, t}$ é normalmente distribuído e que segue

$$
\begin{gathered}
E\left(\epsilon_{i, t} \epsilon_{j, s}\right)=0, i \neq j, t \neq s \\
E\left(\eta_{i} \epsilon_{j, s}\right)=0, \forall i, j, s
\end{gathered}
$$




$$
\begin{aligned}
& E\left(\left(X_{i, t} P_{i t} \tau_{i}\right) \epsilon_{j, s}\right)=0, \forall i, j, s, t \\
& E\left(\left(Z_{i, t} P_{i t} \tau_{i}\right) \epsilon_{j, s}\right)=0, \forall i, j, s, t
\end{aligned}
$$

\subsection{Descrição dos dados}

\subsubsection{Resultado Fiscal e Erros de Previsão}

A amostra consiste de um painel dos 26 estados brasileiros e do Distrito Federal no período de 1995 a 2018.

O resultado fiscal é definido como a diferença entre as receitas e despesas efetivamente realizadas dividida pela população de cada estado. Deste modo, define-se, sendo $D_{r}$ a despesa efetivamente realizada no exercício fiscal, a variável Resultado ${ }_{i t}$ como

$$
\text { Resultado }=\frac{R_{r}-D_{r}}{P}
$$

As receitas e despesas efetivamente realizadas foram obtidas do Sistema de Informações Contábeis e Fiscais do Setor Público Brasileiro (SICONFI) da Secretaria do Tesouro Nacional (STN). A população de cada unidade federativa é obtida do Instituto Brasileiro de Geografia e Estatística (IBGE).

Não considera-se como variável de desempenho fiscal o nível da dívida ou sua taxa de crescimento porque essas variáveis estão relacionadas ao desempenho dos secretários da Fazenda dos governos anteriores. Além disso, existem diferenças expressivas no endividamento dos estados brasileiros.

Para medir os erros de previsão das receitas dos estados segue-se a abordagem de Chatagny e Soguel (2011). Erros absolutos são frequentemente usados (Mocan e Azad (1995), p. 419) a fim de evitar erros negativos e positivos que se compensem. No entanto, como o interesse é no sinal do erro de previsão, eles olham para a diferença entre a receita fixada no orçamento e a receita efetivamente arrecadada dividida pela população, uma vez

que as demais variáveis também serão expressas em termos per capita. Desta forma, os erros de previsão se tornam comparáveis entre os estados.

Os erros de previsão são definidos então pela seguinte expressão:

$$
\text { Erro }=\frac{R_{e}-R_{r}}{P}
$$

Sendo $R_{e}$ a receita estimada para o período na Lei Orçamentária Anual, $R_{r}$ a receita efetivamente realizada no exercício fiscal e P a população da unidade federativa. 
As receitas estimadas no processo orçamentário são obtidas dos Relatórios Resumidos de Execução Orçamentária (RREO), presentes no endereço eletrônico da Secretaria do Tesouro Nacional (STN), ou diretamente das Leis Orçamentárias Anuais aprovadas para cada exercício fiscal, no caso das observações anteriores ao ano de 2001.

Visando o objetivo de captar os efeitos do Secretário do Planejamento sobre a receita prevista no projeto de LOA enviada ao Congresso, idealmente se utilizaria a receita prevista na LOA originalmente enviada. Esta informação, porém, não se encontra disponível de forma abrangente para os estados brasileiros na RREO ou nas demais fontes de dados. Trabalha-se, portanto, com a receita prevista na LOA aprovada, influenciada tanto pelo Secretário do Planejamento quanto pela Assembleia Legislativa.

Existe grande heterogeneidade entre o erro de previsão orçamentária observado nas diversas unidades federativas, como evidenciado na Tabela 1. Visualiza-se que das 27 unidades federativas brasileiras, 21 apresentam maior tendência à superestimação das receitas no período de análise. Existem então evidências preliminares que o comportamento de superestimação é mais comum e a previsão de receita presente nas peças orçamentárias pode não se mostrar um canal efetivo para uma condução prudencial da política fiscal.

Uma primeira análise dos dados também evidencia que a correlação entre resultado fiscal médio e tendência de superestimação da receita não é trivial. Considerando os valores em sua média nestes 24 anos de análise, observa-se a divergência nos erros de previsão dos três primeiros estados a se encontrarem em estado de calamidade financeira: comparativamente aos outros estados, o Rio de Janeiro apresenta forte tendência de superestimação, Minas Gerais tende a subestimação de suas receitas e o Rio Grande do Sul se encontra em posição relativamente intermediária.

\subsubsection{Variáveis de controle}

Visando isolar melhor o efeito das variável explicativa de interesse, que é Erro $_{i t}$, adiciona-se na regressão outras variáveis explicativas do resultado fiscal como controles. A Tabela 2 descreve resumidamente as variáveis de interesse e controle político-institucional.

A primeira variável é dada pelos valores defasados em um período do resultado fiscal uma vez que é conhecida a inércia do desempenho fiscal. A adoção de uma estrutura dinâmica ajuda ainda resolver o problema de autocorrelação da série ((CHATAGNY; SOGUEL, 2011)).

Seguindo os trabalhos anteriores sobre os determinantes dos resultados fiscais, controla-se pela taxa de crescimento real do produto dos estados Crescimento $_{i t}$ (ver por exemplo, Feld e Kirchgässner (2000)).

Como estatísticas consistentes para o nível de desemprego discriminado pelas unidades federativas brasileiras para o período não estão disponíveis, considera-se que o 


\begin{tabular}{|c|c|c|c|c|c|}
\hline \multirow{2}{*}{$\mathrm{UF}$} & \multirow{2}{*}{ Erro } & \multirow{2}{*}{ Resultado } & \multicolumn{3}{|c|}{ Número de observações de Erro de Previsão } \\
\hline & & & Total & Superestimação & Subestimação \\
\hline DF & 813,9 & 152,8 & 24 & 23 & 1 \\
\hline TO & 496,6 & 212,1 & 24 & 23 & 1 \\
\hline RJ & 390,2 & 9,9 & 24 & 21 & 3 \\
\hline PR & 384,1 & 54,9 & 24 & 22 & 2 \\
\hline PI & 344,7 & 35,2 & 16 & 13 & 3 \\
\hline $\mathrm{PE}$ & 251,0 & 34,7 & 24 & 20 & 4 \\
\hline $\mathrm{RN}$ & 230,6 & 38,6 & 24 & 22 & 2 \\
\hline $\mathrm{PB}$ & 190,5 & 18,2 & 24 & 22 & 2 \\
\hline GO & 176,2 & 37,6 & 24 & 20 & 4 \\
\hline ES & 171,5 & 77,9 & 24 & 17 & 7 \\
\hline $\mathrm{RS}$ & 150,0 & 62,4 & 24 & 15 & 9 \\
\hline $\mathrm{SC}$ & 136,9 & 32,0 & 24 & 19 & 5 \\
\hline $\mathrm{SE}$ & 98,8 & 18,8 & 23 & 12 & 11 \\
\hline MS & 71,9 & 76,8 & 24 & 14 & 10 \\
\hline $\mathrm{CE}$ & 71,4 & 36,8 & 24 & 15 & 9 \\
\hline AL & 60,8 & 67,6 & 23 & 18 & 5 \\
\hline MA & 55,7 & 43,5 & 23 & 15 & 8 \\
\hline $\mathrm{AP}$ & 48,0 & 623,0 & 24 & 10 & 14 \\
\hline BA & 17,8 & 25,4 & 24 & 14 & 10 \\
\hline $\mathrm{RO}$ & 16,4 & 113,8 & 24 & 13 & 11 \\
\hline $\mathrm{PA}$ & 7,8 & 46,3 & 24 & 12 & 12 \\
\hline $\mathrm{MG}$ & $-42,5$ & 126,6 & 24 & 9 & 15 \\
\hline $\mathrm{AC}$ & $-46,5$ & 55,9 & 24 & 7 & 17 \\
\hline $\mathrm{MT}$ & $-56,3$ & 147,6 & 24 & 7 & 17 \\
\hline $\mathrm{AM}$ & $-135,3$ & 109,7 & 24 & 5 & 19 \\
\hline $\mathrm{SP}$ & $-213,0$ & 101,9 & 24 & 3 & 21 \\
\hline $\mathrm{RR}$ & $-763,2$ & 445,6 & 22 & 2 & 20 \\
\hline
\end{tabular}

Tabela 1 - Erros de Previsão de Receita e Resultados Fiscais dos Estados Brasileiros, $1995-2018$

crescimento do produto é a melhor proxy do ciclo econômico.

A fim de controlar efeitos de flutuações no produto associados a resultados fiscais inesperados pensou-se em usar as previsões de crescimento econômico presentes nas Leis de Diretrizes Orçamentárias (LDOs) estaduais. No entanto, a baixíssima variabilidade horizontal entre estas previsões, que normalmente são réplicas da previsão 'oficial' de crescimento econômico nacional utilizada pela União, não permitiriam que isso fosse possível.

Assumindo-se que estados altamente dependentes de recursos da União teriam menos cuidado ao realizarem suas estimativas de receitas, inclui-se a variável Transferencia $a_{i t}$ que corresponde ao percentual de receitas advindas de transferências da União.

Considera-se uma variável dummy indicando o caráter ideológico do governo esta- 


\begin{tabular}{|c|c|c|c|}
\hline Variável & Descrição & Métrica & Fonte \\
\hline Erro & $\begin{array}{l}\text { Erro de previsão do período, } \\
\text { pela métrica de Chatagny, Soguel (2011) }\end{array}$ & Reais/Habitante & STN \\
\hline Resultado & Resultado fiscal do período, em valores per capita & Reais/Habitante & STN \\
\hline Crescimento & Taxa de crescimento real do PIB estadual & Percentual & IBGE \\
\hline Transferências & Percentual de Receitas advindas de transferências da União & Percentual & STN \\
\hline GovExperiência & $\begin{array}{l}\text { Indicador de estabilidade política, } \\
\text { contando quantos anos o partido do(a) } \\
\text { governador(a) passou no cargo }\end{array}$ & Numérica & Elaboração Própria \\
\hline GovEsquerda & $\begin{array}{l}\text { Indicador da ideologia do(a) governador(a), } \\
\text { através de sua filiação partidária }\end{array}$ & 1: Esquerda 0: Outros & Baseado en Rodrigues (2002) \\
\hline Concordância & $\begin{array}{l}\text { Indicador da força legislativa do governo, } \\
\text { sendo o quociente partidário do partido } \\
\text { d(a) governador(a) na respectiva eleição }\end{array}$ & Númerica & TSE \\
\hline Coligação & $\begin{array}{l}\text { Número de partidos na coligação } \\
\text { eleita para o governo estadual }\end{array}$ & Numérica & TSE \\
\hline Concorrência & $\begin{array}{l}\text { Indicador de concorrência eleitoral, } \\
\text { medida pelo número efetivo de partidos (NEP) }\end{array}$ & Numérica & TSE \\
\hline FragLegis & $\begin{array}{l}\text { Medida da dispersão partidária da } \\
\text { Assembleia Legislativa estadual }\end{array}$ & Númerica & TSE \\
\hline ÍndiceAlesina & $\begin{array}{l}\text { Índice da Qualidade das Instituições } \\
\text { Orçamentárias dos estados brasileiros }\end{array}$ & Numérica & Leal (2020) \\
\hline PreEleitoral & Binária referente aos anos anteriores a eleições estaduais & Binária & Elaboração Própria \\
\hline Eleitoral & Binária referente aos anos com eleições estaduais & Binária & Elaboração Própria \\
\hline PosEleitoral & Binária referente aos anos posteriores a eleições estaduais & Binária & Elaboração Própria \\
\hline
\end{tabular}

Tabela 2 - Descrição e fonte das principais variáveis

dual. A variável GovEsquerda $a_{i t}$ indica a ideologia do governador, tomando como medida sua afiliação partidária. Devido às severas restrições na classificação ideológica dos partidos brasileiros, especialmente considerando as mudanças drásticas nesta classificação relativa entre as 27 UFs brasileiras e os 24 anos da análise proposta, esta variável será utilizada somente por questões de robustez. Usa-se como base a classificação ideológica dos partidos brasileiros com base em Rodrigues (2002); a variável GovEsquerda $a_{i t}$ assumirá valor 1 no caso de partidos de esquerda, e valor 0 caso contrário. Especificações alternativas, tal como as referenciadas em Júnior e Power (2018), apresentam virtualmente a mesma gradação dos partidos entre governadores estaduais.

A variável GovExperiência $a_{i t}$ informa quantos anos o partido do governador passou no cargo e atua como proxy da estabilidade política no Executivo estadual e permite filtrar melhor a experiência específica dos secretários. De outro modo, é possível argumentar que a experiência dos secretários atuaria somente como proxy de estabilidade política ((MOESSINGER, 2014)).

Seguindo Goeminne, Geys e Smolders (2008), utiliza-se o número de partidos Coligacao $_{i t}$ na coalizão governamental como medida da fragmentação do governo.

Além disso, utiliza-se de forma a captar a competição política o Número Efetivo de Partidos (Concorrencia $a_{i t}$ ) que mensura o grau de fragmentação do sistema partidário, através da ponderação da força relativa das legendas que compõem a Assembleia Legislativa 
de cada estado. O valor calculado aponta a quantidade de partidos com alguma relevância em um sistema político, calculado dividindo-se 1 pelo somatório do quadrado das proporções de votos ou de cadeiras obtidos pelos partidos em uma dada eleição. É uma variável frequentemente utilizada como medida do grau de dispersão da competição política em um país, isto é, para saber se a disputa por cargos envolve poucos ou muitos partidos (POLITICA, 2018a).

Velasco (2000) utiliza o conceito de concordância política para avaliar a proximidade de objetivos políticos do Poder Executivo e do Poder Legislativo. Para o caso dos estados brasileiros, isto seria captado pela proporção de partidos governistas na Assembleia Legislativa Estadual para cada mandato. Como medida de concordância política, usa-se um indicador Concordancia $a_{i t}$ dado pelo quociente partidário do partido do governador na última eleição para deputado estadual. O quociente partidário representa o número de vagas que o partido ou coligação obteve, excluindo as vagas distribuídas por média, e é calculado pela divisão do número de votos válidos do partido pelo quociente eleitoral (POLITICA, 2018b).

Inclui-se ainda como controle FracLegis $s_{i t}$, uma medida de fracionalização para medir a dispersão partidária do Legislativo. Ela indica qual a probabilidade de dois deputados estaduais eleitos, tomados ao acaso, pertencerem a partidos diferentes. Pode-se supor que assembleias legislativas mais fragmentadas tornariam mais difícil o processo de aprovação de orçamentos manipulados politicamente, além de tornar a fiscalização de seu cumprimento mais incisiva, visto que é realizada por maior número de agentes. Por isso, espera-se que o efeito da fragmentação legislativa sobre o resultado fiscal seja positivo, e que o principal canal de atuação seja através da redução dos erros orçamentários, visto que a principal manifestação da Assembleia Legislativa na política fiscal é através do rito de planejamento orçamentário ex ante. Por outro lado, a fracionalização pode levar ao enfraquecimento dos agentes políticos representados na Assembleia Legislativa, tornando-os mais suscetíveis ao Poder Executivo, visto a ausência de forças com real poder de barganha (POLITICA, 2018a).

Utilizando das mudanças nas normas orçamentárias dos estados brasileiros e do Distrito Federal no período de 1995 a 2016, Leal (2020) constrói um índice da qualidade orçamentária dos estados brasileiros, adaptando a metodologia proposta por Alesina et al. (1999). A proposta original de Alesina et al. (1999) é a de aplicar um questionário de dez questões referentes às instituições orçamentárias dos países latino-americanos, construindo assim um índice de notas que informam sobre o quão hierárquicas (isto é, disciplinadas, mandatórias, transparentes e centralizadas) são as regras fiscais referentes ao processo orçamentário de cada país.

Leal (2020) responde o questionário original de Alesina et al. (1999) usando a análise documental das mudanças no processo orçamentário de cada estado. Em geral, as regras 
orçamentárias referentes ao orçamento são horizontalmente aplicadas para todos os entes subnacionais; não obstante, foram encontrados diferentes formas de diferenciar os processos dos estados, ponderando, por exemplo, a flexibilização de regras referentes à operações de crédito dos estados-sede da Copa do Mundo de Futebol de 2014 e leis estaduais que trazem limitações especiais ao aumento de despesas por emendas parlamentares. Responde-se as dez questões do questionário original de Alesina et al. (1999) através das normas constitucionais e específicas para cada estado entre 1995 e 2016, estabelecendo notas de 1 a 10 em cada quesito. Por fim, o índice completo está entre 0 e 100 e é composto pela soma das respostas em cada um dos quesitos ${ }^{5}$

Usa-se esse índice, denominado ÍndiceAlesina, para captar o efeito de mudanças de normas orçamentárias sobre as outras variáveis. Também explora-se o efeito do índice de qualidade orçamentária, defasado um período, sobre os erros de previsão orçamentária.

Como usual na literatura, adota-se variáveis binárias representando anos de eleição, no caso de Eleitoral $_{t}$, mas também os anos anteriores aos anos de eleição PreEleitoral e $_{t}$

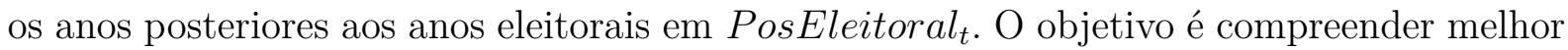
as possíveis consequências do ciclo eleitoral sobre o resultado fiscal dos estados, como estabelecido pela literatura sobre ciclos eleitorais oportunistas.

A Tabela 3 trata das estatísticas descritivas das principais variáveis de interesse e controle do trabalho.

\begin{tabular}{lccccc}
\hline \multicolumn{1}{c}{ Variável } & Obs. & Média & D.P. & Min & Max \\
\hline Erro & 635 & 108,39 & 441,42 & $-2.794,40$ & $2.954,12$ \\
Resultado & 635 & 106,43 & 267,47 & $-508,39$ & $2.352,60$ \\
Crescimento & 609 & 6,01 & 7,73 & $-17,21$ & 78,53 \\
Transferências & 635 & 0,38 & 0,21 & 0,03 & 1,37 \\
GovEsquerda & 635 & 0,35 & 0,48 & 0,00 & 1,00 \\
GovExperiência & 635 & 3,36 & 3,64 & 0,00 & 23,00 \\
Concordância & 583 & 7,71 & 8,17 & 0,51 & 71,82 \\
Coligação & 635 & 8,20 & 4,10 & 1,00 & 21,00 \\
Concorrência & 587 & 8,02 & 3,13 & 1,58 & 31,58 \\
FracLegis & 583 & 0,87 & 0,05 & 0,65 & 0,95 \\
ÍndiceAlesina & 635 & 64,44 & 5,72 & 52,76 & 77,16 \\
\hline
\end{tabular}

Tabela 3 - Estatísticas Descritivas das principais variáveis

5 Cabe cautela pelo fato da variabilidade do índice, tanto entre estados quanto entre anos, ser muito pequena. O estado com maior valor médio no período é Pernambuco com valor 69,77, enquanto os menores são Rio de Janeiro e Bahia com média de 61,99. 


\subsection{Características dos secretários}

\subsubsection{A construção da base de dados}

Como não existe uma base de dados completa e abrangente referente as características dos Secretários da Fazenda e do Planejamento, a base utilizada foi construída a partir diversas fontes de dados.

Informações iniciais foram obtidas no Banco de Dados sobre os Secretaria dos Estados do CEPESP Data ${ }^{6}$, que compila informações de nomeação e exoneração dos secretários estaduais em diários oficiais, em conjunto com informações de filiação partidária originárias dos bancos de dados disponibilizados pelo Tribunal Superior Eleitoral (TSE).

Esta base de dados não possui informações sobre o estado do Amapá e se limita ao período de 1995 a 2014, tendo como informações originais o nome, sexo, data de nascimento, data de nomeação e de exoneração, partido político, formação acadêmica, profissão antes de nomeado e se este já era funcionário público e/ou trabalhava na secretaria no momento da nomeação dos secretários estaduais.

Como o objetivo é construir um painel abrangente dos Secretários da Fazenda e do Planejamento no período proposto, a base de dados do CEPESP Data se mostrou insuficiente. A partir dela conseguiu-se informações do nome do Secretário somente em cerca de 60\% das observações do painel. Notavelmente, grau de instrução, curso superior, profissão antes de nomeado e data de nascimento apresentaram uma grande quantidade de valores ausentes.

A consulta ao banco de dados de filiados de responsabilidade do Tribunal Superior Eleitoral (TSE) revelou também a incompletude das informações originalmente disponíveis de filiação partidária, mesmo para os secretários cujos nomes eram conhecidos.

Para completar as informações, foram utilizados os diários oficiais que trazem informações sobre as nomeações e exonerações de secretários, com apoio de notícias e publicações de outros veículos de imprensa e páginas oficiais das secretarias.

Também foram utilizadas informações do histórico de secretários através de pedidos feitos através da Lei de Acesso à Informação (LAI), às respectivas secretarias estaduais.

No que diz respeito às lacunas no histórico acadêmico e profissional dos secretários, foram incorporadas informações disponíveis sobre a trajetória acadêmica e profissional dos secretários disponíveis na internet, especialmente através da Plataforma Lattes ${ }^{7}$. Os nomes dos secretários titulares dos cargos foram obtidos através da base de filiados do TSE, de modo que foi possível obter uma informação precisa da filiação partidária destes

6 Descrição do projeto disponível em https://cepespdata.io/about-state-secretaries. Consulta em $16 / 09 / 2020$.

7 Disponível em http://lattes.cnpq.br/. As consultas foram realizadas ao longo do ano de 2020 quando foi feita a construção da base de dados. 
de acordo com seu ano à frente da pasta.

Outra questão importante diz respeito à existência de secretarias unificadas, normalmente chamadas de Secretaria de Fazenda e Planejamento ou Secretaria de Economia, que agregam as duas funções. O Distrito Federal tem uma secretaria unificada durante todo o período de estudo. A tendência depois das eleições de 2018 é de unificação dessas pastas, especialmente após a adoção deste sistema pelo Rio de Janeiro em seu período de consolidação fiscal (2016 em diante) e a união dessas pastas pelo Governo Federal em 2019. Durante o período de análise, no entanto, somente 38 observações do painel se referem a situações de uma pasta unificada e as características de seus secretários são vistas como simultaneamente referentes ao Secretário do Planejamento e ao Secretário da Fazenda.

Naturalmente, surgem dificuldades referentes ao fato que um painel anual não considera diferentes mudanças no cargo no decorrer do mesmo ano. Considerando que o principal interesse em relação ao Secretário do Planejamento é a elaboração das peças orçamentárias referentes ao ano seguinte, determina-se para cada ano o Secretário do Planejamento que estava no cargo no mês de Setembro, mês em que ocorre o envio do projeto de Lei Orçamentária Anual. Em relação aos Secretários da Fazenda, tal decisão se mostra mais delicada, visto a relevância destes para a condução da política fiscal durante toda a duração do ano. Opta-se por determinar em cada ano o Secretário que passou mais tempo no cargo no decorrer do ano.

A partir da soma destes esforços, consolida-se uma base de dados suficientemente exaustiva do perfil dos Secretários da Fazenda e do Planejamento. Considerando-se as 648 observações do painel em questão (27 unidades federativas em 24 anos). São informações referentes a 241 Secretários do Planejamento e 221 Secretários da Fazenda. As informações referentes à idade do incumbente quando nomeado não são utilizadas, devido à pouca relevância desta para a literatura teórica e empírica e ao comprometimento da base de dados pela grande quantidade de informações que faltam. Do universo de 648 observações, dispõese da data de nascimento de somente 402 observações de Secretários do Planejamento e 375 Secretários da Fazenda.

\subsubsection{Variáveis}

As características de secretários são divididas entre características pessoais, profissionais, acadêmicas e partidárias.

A única característica pessoal disponível é a variável binária $S e x o_{i t}$ que assume valor 1 quando é uma mulher está no cargo e 0 caso contrário. Chama atenção o percentual baixo de mulheres no comando das pastas ( $8 \%$ das observações na pasta do Planejamento e $5 \%$ na Fazenda).

Para captar o impacto da experiência do incumbente na secretaria sobre a política 
fiscal, utiliza-se a variável numérica $\operatorname{Exp}_{i t}$ que conta quantos anos o secretário passou no comando da pasta. Alguns secretários notavelmente longevos no cargo tornam a distribuição dessa variável especialmente assimétrica. Exemplos são os secretários do Planejamento Haroldo Eurico Amoras dos Santos (13 anos em Roraima), Gilberto do Carmo Lopes Siqueira (11 anos no cargo no Acre), os secretários da Fazenda Oswaldo dos Santos Jacintho (10 anos no Maranhão) e Carlos Mauro Benevides Filho (10 anos no Ceará). Também digno de nota é o secretário da Economia do Distrito Federal, pasta que une as responsabilidades de Fazenda e Planejamento, Valdivino José de Oliveira, passou 10 anos no cargo.

Para captar a trajetória profissional, utiliza-se das variáveis binárias $F u n c P u b_{i t}$ que assume valor 1 quando o secretário já era funcionário público quando nomeado, e TnSecretaria $_{i t}$ que assume valor 1 quando o secretário já trabalhava na secretaria em questão na data de sua nomeação.

As características acadêmicas são dadas pelo grau de instrução do secretário

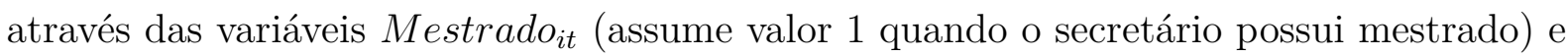
Doutorado $_{i t}$, quando este possui doutorado completo. A grande maioria dos secretários possui ensino superior completo, sendo apenas quinze observações de Secretários da Fazenda e duas observações de Secretários do Planejamento cujo grau de instrução é ensino médio completo.

Adotam-se também variáveis binárias referentes à área de formação dos Secretários: Economia $_{i t}$, Direito $_{i t}$, Finanças $_{i t}$ (agrupando as faculdades de Administração, Gestão e Contabilidade) e Engenharia ${ }_{i t}$, sendo as observações com somente ensino médio completo ou formação em outros cursos usadas como base de comparação.

Como forma de mensurar as características político-partidárias dos secretários, utilizam-se as variáveis binárias Filiado $i t$ que assume valor 1 quando o secretário era filiado a algum partido político durante o seu período frente à pasta, PtdGovernador ${ }_{i t}$ com valor 1 quando o secretário se encontra filiado ao mesmo partido do governador em exercício. 


\begin{tabular}{clccccc}
\hline Secretário & \multicolumn{1}{c}{ Variável } & Obs. & Média & D.P. & Min & Max \\
\hline & Sexo & 623 & 0,08 & 0,27 & 0 & 1 \\
& Exp & 623 & 1,76 & 2,24 & 0 & 13 \\
& FuncPub & 623 & 0,40 & 0,49 & 0 & 1 \\
TnSecretaria & 623 & 0,06 & 0,24 & 0 & 1 \\
& Mestrado & 623 & 0,19 & 0,39 & 0 & 1 \\
& Doutorado & 623 & 0,32 & 0,47 & 0 & 1 \\
Planejamento & Economia & 623 & 0,34 & 0,47 & 0 & 1 \\
& Direito & 623 & 0,15 & 0,36 & 0 & 1 \\
& Finanças & 623 & 0,09 & 0,29 & 0 & 1 \\
& Engenharia & 623 & 0,20 & 0,40 & 0 & 1 \\
& Filiado & 623 & 0,56 & 0,50 & 0 & 1 \\
& PtdGovernador & 623 & 0,36 & 0,48 & 0 & 1 \\
& PtdEsquerda & 623 & 0,22 & 0,41 & 0 & 1 \\
\hline Sexo & 619 & 0,05 & 0,22 & 0 & 1 \\
Exp & 619 & 1,62 & 1,93 & 0 & 11 \\
& FuncPub & 619 & 0,47 & 0,50 & 0 & 1 \\
TnSecretaria & 619 & 0,11 & 0,31 & 0 & 1 \\
& Mestrado & 619 & 0,12 & 0,32 & 0 & 1 \\
& Doutorado & 619 & 0,25 & 0,43 & 0 & 1 \\
Economia & 619 & 0,35 & 0,48 & 0 & 1 \\
& Direito & 619 & 0,17 & 0,38 & 0 & 1 \\
& Finanças & 619 & 0,16 & 0,36 & 0 & 1 \\
Engenharia & 619 & 0,13 & 0,34 & 0 & 1 \\
& Filiado & 619 & 0,43 & 0,50 & 0 & 1 \\
& PtdGovernador & 619 & 0,31 & 0,46 & 0 & 1 \\
& PtdEsquerda & 619 & 0,16 & 0,37 & 0 & 1 \\
\hline
\end{tabular}

Tabela 4 - Estatísticas Descritivas das variáveis referentes aos Secretários

Por fim, a variável binária PtdEsquerda assume valor 1 quando o secretário está filiado a algum partido de esquerda e 0 caso contrário ${ }^{8}$. Devido às dificuldades envolvendo o estabelecimento de um espectro de ideologia partidária estável dentre os estados brasileiros, tanto entre as 27 unidades federativas e nos 24 anos de análise, esta variável será utilizada somente para teste de robustez; os resultados gerais deste trabalho não se alteram com sua inclusão ou exclusão.

A Tabela 4 traz estatísticas descritivas referentes as variáveis dos secretários.

Primeiramente observa-se que não existem diferenças importantes entre o perfil do secretário escolhido para a pasta da Fazenda e aquele escolhido para a pasta do Planejamento.

8 Dentre a totalidade dos partidos observados na gestão estadual, são considerados como partidos ideologicamente à esquerda PCdoB, PDT, PMN, PPS, PROS, PSB, PT e PV, nos baseando no trabalho de Rodrigues (2002). 
Observa-se que, em média, os Secretários do Planejamento possuem um perfil mais acadêmico (mais observações de mestres e doutores) e político (mais observações de filiação partidária, frequentemente ao mesmo partido do governador do que seus colegas na pasta da Fazenda. Mais precisamente, cerca de $64 \%$ das observações em que Secretários do Planejamento são filiados, estes são do mesmo partido do governador.

A proporção de secretários com formação em Economia e Direito nas duas pastas é similar, mas a pasta de Planejamento foi ocupada mais vezes por engenheiros, enquanto a pasta da Fazenda foi ocupada mais vezes por secretários com graduação em finanças. 


\section{Erro de Previsão e Resultado Fiscal}

\subsection{Metodologia}

Inicialmente estima-se a equação 3.1 usando mínimos quadrados ordinários (MQO) com efeitos fixos de estado e de tempo e desvios-padrão clusterizados por estado e ano.

Contudo, é sabido que a inclusão da variável dependente defasada como regressor e a presença de efeitos fixos de estado (colocar a letra grega correspondente aqui) tornam o estimador de MQO inconsistente.

Uma alternativa seria então usar estimadores específicos para dados em painel. O estimador de efeitos fixos (fixed effects ou least square dummy variable) e de efeitos aleatórios (RE ou mínimos quadrados generalizados) resolvem o problema de omissão de variáveis ao remover a heterogeneidade invariante no tempo. Contudo, não resolvem o problema de correlação entre a variável dependente defasada e o termo de erro transformado (Baltagi (2008), capítulo 8).

A inclusão da variável dependente na regressão de efeitos fixos resulta no viés de Nickell (Nickell bias). De acordo com Nickell (1981), o estimador de efeitos fixos é não viesado somente se $\mathrm{T}$ tende a infinito, mas gera coeficientes viesados quando o painel é curto. Dado $\mathrm{T}=24$, os coeficientes seriam viesados em $1 / \mathrm{T}$, ou seja, $4 \%$.

Diante disso, é necessário utilizar métodos alternativos de estimação. Estima-se então a equação 3.11 usando também o método generalizado de momentos sistêmico (GMM-sys), desenvolvido por Arellano e Bover (1995) e Blundell e Bond (1998).

Outras ponderações devem ser feitas para que os resultados obtidos possam ser avaliados corretamente.

Se a variável dependente é o saldo fiscal e a variável de interesse é o erro de previsão das receitas, aparece imediatamente o problema de endogeneidade das duas variáveis. Ambas são funções de uma terceira variável, a receita efetivamente realizada $R_{r}$, que é dependente do produto. É possível conjecturar que os estados se comportam de modo a definir para o ano fiscal um nível de gastos $G$ igual à receita prevista $R_{t}^{e}$, e quaisquer desvios do resultado fiscal e do erro de previsão orçamentária sejam derivados somente do comportamento errático da receita realizada durante a execução orçamentária. Este comportamento imprevisto da receita realizada pode advir de frustrações de expectativas macroeconômicas, como também de um amplo conjunto de fatores que comprometem o fisco e a capacidade arrecadatória de cada ente subnacional. Se esta conjectura se mostrasse inteiramente válida, a regressão do resultado fiscal sobre o erro de previsão seria espúria. 
Argumenta-se que, apesar da relevância do aspecto 'acidental' do erro de previsão orçamentária resultante dos eventos inesperados ocorridos no decorrer do ano fiscal, frequentemente existe um componente 'proposital' nas previsões de receita.

O uso de várias variáveis de caráter institucional e político-eleitoral referentes aos estados brasileiros e de efeitos fixos de estado e de tempo, por sua vez, reduzem a possibilidade de problemas de omissão de variáveis.

Trabalha-se, portanto, com a implausibilidade da ideia de causalidade reversa (resultados fiscais observados ex post causarem desvios da previsão de receita ex ante) e a improbabilidade de omissão de uma terceira variável relevante.

Sendo impossível eliminar todas as possíveis fontes de endogeneidade, os resultados devem ser interpretados com cautela e indicativos de correlação mais do que de causalidade.

No que diz respeito às características dos secretários poderia-se argumentar, inicialmente, que existe um problema de viés de seleção à medida que uma situação econômica adversa ou altos déficits orçamentários passados poderiam influenciar a escolha pelo governador do secretário da Fazenda ou do Planejamento ${ }^{9}$. Por exemplo, em épocas de receitas frustradas e más condições econômicas, o governador pode estar mais propenso a escolher um Secretário da Fazenda com melhor formação acadêmica, ou que já trabalhasse na Secretaria e desta forma possuísse maior conhecimento da burocracia da pasta. Foram realizados testes para estudar se há diferenças significativas na contratação de Secretários da Fazenda um período após recessão econômica dos estados. Não foram encontradas diferenças estatisticamente significativas dos incumbentes da pasta da Fazenda como mostram os resultados da Tabela 19 no apêndice.

Uma outra possibilidade de viés endógeno resultaria do comportamento do eleitorado. As preferências eleitorais em cada estado poderiam ser os verdadeiros determinantes tanto da trajetória das variáveis fiscais, à medida que estas poderiam ser determinadas pela plataforma política eleita, quanto das características dos secretários responsáveis pelo orçamento, à medida que estes também representariam as escolhas do governante eleito. Esta possibilidade parece remota, especialmente no contexto dos estados brasileiros. Espera-se que, para o eleitor mediano, as características dos secretários escolhidos para as pastas da Fazenda ou do Planejamento sejam aleatórias; não espera-se que alguma promessa referente às características do responsável por uma dessas pastas, ou mesmo que a tendência de superestimação do orçamento (assunto que raramente merece atenção da mídia e da plataforma eleitoral) sejam relevantes para a escolha eleitoral do governador(CHATAGNY, 2013).

9 Uma possível alternativa para lidar com essa causalidade reversa seria adotar a mesma estratégia de Jones e Olken (2005) e usar somente mudanças 'exógenas' no secretário, como no caso de mortes inesperadas de incumbentes. Esta linha de estratégia é inapropriada no caso em questão, devido às severas restrições no número de observações da base de dados. 


\subsection{Resultados}

A Tabela 5 apresenta os resultados da estimação da equação 3.1 sem levar em conta as características dos secretários da Fazenda.

\begin{tabular}{|c|c|c|c|c|c|c|}
\hline Variável Explicada = Resultado & (1) & (2) & (3) & (4) & $(5)$ & (6) \\
\hline Erro & $\begin{array}{l}-0.0634 \\
(0.0757)\end{array}$ & $\begin{array}{l}-0.0778 \\
(0.0819)\end{array}$ & $\begin{array}{c}-0.0805^{* * *} \\
(0.0156)\end{array}$ & $\begin{array}{c}-0.105^{* * *} \\
(0.0170)\end{array}$ & $\begin{array}{c}-0.240^{* * *} \\
(0.0720)\end{array}$ & $\begin{array}{c}-0.332^{* * *} \\
(0.115)\end{array}$ \\
\hline Resultado (defasado) & $\begin{array}{c}0.577^{* *} \\
(0.244)\end{array}$ & $\begin{array}{c}0.533^{* *} \\
(0.242)\end{array}$ & $\begin{array}{c}0.582^{* * *} \\
(0.0370)\end{array}$ & $\begin{array}{c}0.523^{* * *} \\
(0.0389)\end{array}$ & & \\
\hline Crescimento & $\begin{array}{l}-1.017 \\
(1.637)\end{array}$ & $\begin{array}{l}-0.915 \\
(1.869)\end{array}$ & $\begin{array}{l}-1.309 \\
(0.936)\end{array}$ & $\begin{array}{c}-1.575^{*} \\
(0.947)\end{array}$ & $\begin{array}{l}-18.70 \\
(12.98)\end{array}$ & $\begin{array}{l}-7.888 \\
(12.74)\end{array}$ \\
\hline ÍndiceAlesina & & $\begin{array}{l}-1.563 \\
(4.445)\end{array}$ & & $\begin{array}{l}-2.933 \\
(2.962)\end{array}$ & & $\begin{array}{c}37.58 \\
(62.12)\end{array}$ \\
\hline Transferências & & $\begin{array}{l}-121.9 \\
(125.3)\end{array}$ & & $\begin{array}{l}-32.00 \\
(65.75)\end{array}$ & & $\begin{array}{c}23.90 \\
(594.3)\end{array}$ \\
\hline GovExperiência & & $\begin{array}{l}-2.988 \\
(3.461)\end{array}$ & & $\begin{array}{l}-3.205 \\
(2.034)\end{array}$ & & $\begin{array}{c}36.62 \\
(28.78)\end{array}$ \\
\hline Coligação & & $\begin{array}{l}-6.784 \\
(4.422)\end{array}$ & & $\begin{array}{c}-5.180^{* * *} \\
(1.560)\end{array}$ & & $\begin{array}{c}15.22 \\
(29.61)\end{array}$ \\
\hline Preeleitoral & & $\begin{array}{c}111.1 \\
(88.78)\end{array}$ & & $\begin{array}{c}-153.8^{* * *} \\
(37.80)\end{array}$ & & \\
\hline Eleitoral & & $\begin{array}{c}-32.84^{* * *} \\
(9.412)\end{array}$ & & $\begin{array}{l}-19.83 \\
(37.96)\end{array}$ & & \\
\hline Poseleitoral & & $\begin{array}{c}246.2^{* * *} \\
(30.14)\end{array}$ & & $\begin{array}{l}-14.57 \\
(39.05)\end{array}$ & & \\
\hline Concordância & & $\begin{array}{c}15.11 \\
(11.49)\end{array}$ & & $\begin{array}{c}12.05 \\
(10.46)\end{array}$ & & $\begin{array}{l}-8.966 \\
(143.3)\end{array}$ \\
\hline Concorrência & & $\begin{array}{c}3.998 \\
(5.680)\end{array}$ & & $\begin{array}{c}1.865 \\
(2.207)\end{array}$ & & $\begin{array}{c}29.74 \\
(55.14)\end{array}$ \\
\hline FracLegis & & $\begin{array}{l}-358.0 \\
(341.1)\end{array}$ & & $\begin{array}{l}-271.2 \\
(200.9)\end{array}$ & & $\begin{array}{c}193.8 \\
(4,532)\end{array}$ \\
\hline Constante & $\begin{array}{c}222.2^{* * *} \\
(25.06)\end{array}$ & $\begin{array}{l}574.8^{*} \\
(298.0)\end{array}$ & $\begin{array}{c}196.1^{* * * *} \\
(36.55)\end{array}$ & $\begin{array}{c}790.6^{* * *} \\
(287.2)\end{array}$ & $\begin{array}{l}391.3^{*} \\
(214.9)\end{array}$ & $\begin{array}{l}-3,569 \\
(5,289)\end{array}$ \\
\hline Estimador & OLS & OLS & GLS & GLS & GMM & GMM \\
\hline Controles Políticos & Não & Sim & Não & Sim & Não & Sim \\
\hline Observações & 602 & 562 & 602 & 562 & 609 & 569 \\
\hline
\end{tabular}

Tabela 5 - Regressão do Erro de Previsão sobre o Resultado Fiscal.

Em concordância com a hipótese principal, de que a sobre(sub)-estimação da arrecadação $\left(\right.$ Erro $\left._{i t}\right)$ pioraria (melhoraria) o resultado fiscal do ano corrente, estima-se que o coeficiente da principal variável explicativa Erro $_{i t}$ é estatisticamente significativo e negativo. Considerando a validade da principal especificação adotada, tem-se que, para as unidades federativas brasileiras, para cada real per capita de sobre-estimação da receita na fase de planejamento do orçamento, espera-se um balanço fiscal ex post menor entre 0,08 e 0,33 real per capita. Alternativamente, é possível interpretar este coeficiente como uma medida inversa da capacidade da execução do orçamento de se ajustar à um comportamento 
'inesperado' da receita arrecadada. Assim, entre 67\% e 92\% do erro de previsão de receita na fase do planejamento do orçamento é corrigida no decorrer do ano fiscal, através dos mecanismos discricionários presentes na fase de execução do orçamento.

A correlação entre o crescimento do PIB real e o resultado fiscal é drasticamente mitigada com a inclusão das variáveis binárias referentes aos estados e anos, que carregam em si a correlação das características particulares de anos de alto (ou baixo) crescimento econômico em todo o país, além de estados com trajetórias peculiares de crescimento do PIB.

O resultado fiscal demonstra possuir alta dependência intertemporal, observada no poder explicativo dos resultados defasados.

As variáveis político-institucionais de controle são coletivamente significativas e possuem poder explicativo sobre o resultado fiscal de cada período (o teste formal de significância conjunta possui estatística chi2 $(10)=42.2$, com p-valor 0.00 , rejeitando a hipótese nula de que esse conjunto de variáveis não é estatisticamente significativo).

Notavelmente, o coeficiente referente ao número de partidos que compõem a coligação do governador eleito (Coligação $o_{i t}$ ) se mostrou fortemente significativo, e relacionado à piores resultados fiscais. Tal resultado corrobora a validade do arcabouço teórico de política fiscal em governos fragmentados e ao problema de common pool ${ }^{10}$ do orçamento público, e ilustram as dificuldades de condução de uma política fiscal austera em governos altamente fragmentados.

Devido às dificuldades de discriminar ideologia partidária no Brasil, especialmente considerando as particularidades de cada uma das unidades federativas nos 24 anos de análise, o modelo base foi estimado sem a variável binária referente à ideologia do governador. Como é possível ver na Tabela 20 do apêndice os resultados são robustos à inclusão desta variável.

As variáveis binárias referentes ao ciclo eleitoral apresentaram coeficientes pouco robustos. Observa-se, porém, uma tendência de que anos pré-eleitorais se mostram relacionados à uma piora no resultado fiscal. Possivelmente, o ímpeto de realizar maiores gastos com objetivo de garantir a reeleição do grupo político do poder se manifestaria nos anos anteriores aos anos eleitorais, em receio aos possíveis impactos negativos de credibilidade considerando a maior visibilidade das contas públicas nos anos eleitorais.

Uma questão importante é se os efeitos dos erros de previsão sobre o resultado fiscal são simétricos entre os casos em que a receita é superestimada e subestimada. A

10 Em intuição estabelecida pela primeira vez na obra de Buchanan e Tullock (1962), observa-se sobre o orçamento público o tradicional problema de 'tragédia dos comuns', em que os grupos de interesse do gasto público, em governos fragmentados sem suficiente poder de coerção central, não internalizam os custos de suas demandas sobre a restrição de recursos compartilhada considerando 'direitos de propriedade' não-definidos sobre as receitas do governo. 


\begin{tabular}{lcccccc}
\hline Variável Explicada = Resultado & $(1)$ & $(2)$ & $(3)$ & $(4)$ & $(5)$ & $(6)$ \\
\hline \multirow{2}{*}{ Superestimação } & & & & & & \\
& 0.0396 & 0.0307 & 0.00658 & -0.0129 & -0.0243 & -0.0347 \\
Subestimação & $(0.0673)$ & $(0.0774)$ & $(0.0197)$ & $(0.0218)$ & $(0.0959)$ & $(0.227)$ \\
& $-0.249^{* *}$ & -0.249 & $-0.237^{* * *}$ & $-0.247^{* * *}$ & $-0.465^{* * *}$ & $-0.507^{* * *}$ \\
Resultado (defasado) & $(0.126)$ & $(0.169)$ & $(0.0282)$ & $(0.0288)$ & $(0.0994)$ & $(0.171)$ \\
& $0.542^{*}$ & $0.506^{* *}$ & $0.541^{* * *}$ & $0.489^{* * *}$ & & \\
Crescimento & $(0.279)$ & $(0.245)$ & $(0.0364)$ & $(0.0381)$ & & \\
& -0.706 & -0.626 & -0.979 & -1.246 & -13.49 & -4.100 \\
Estimador & $(1.501)$ & $(1.127)$ & $(0.911)$ & $(0.924)$ & $(10.44)$ & $(12.36)$ \\
Controles Político-Institucionais & OLS & OLS & GLS & GLS & GMM & GMM \\
Observações & Não & Sim & Não & Sim & Não & Sim \\
\hline
\end{tabular}

Nota: ${ }^{* * *}$ indica significância estatística ao nível de $1 \%,{ }^{* *}$ de $5 \%$ e * ao nível de $10 \%$.

Tabela 6 - Regressão da Erro de Previsão, segmentado entre super e subestimação, sobre o Resultado Fiscal

simetria entre os efeitos seria evidência favorável de que o processo orçamentário de um país e os mecanismos presentes na execução do orçamento são capazes de censurar tanto o comportamento de subestimar a receita visando uma condução mais austera, quanto o de superestimar a receita como meio de elevar as despesas. Seguindo Chatagny e Soguel (2011), estima-se regressões alternativas com a variável Erro segmentada entre as observações em que a receita é superestimada e as observações de subestimação conforme a equação 4.1.

$$
\begin{aligned}
& \text { Resultado }_{i t}=\beta_{1} \text { Superestimação }_{i t}+\beta_{2} \text { Subestimação }_{i t}+ \\
& \gamma \text { Resultado }_{i t-1}+\delta \text { Cresc }_{i t}+\mu P_{i t}+\eta_{i}+\tau_{t}+\epsilon_{i t}
\end{aligned}
$$

Os resultados das estimações alternativas com a variável Erro segmentada entre superestimações e subestimações são apresentados na Tabela 6 .

Testes de simetria são feitos entre o coeficiente do erro superestimado e do erro subestimado, e estes se encontram na Tabela 7.

\begin{tabular}{lc}
\hline H0: Superestimação - Subestimação $=0$ \\
\hline OLS & Prob $>$ chi2 $=0.0329$ \\
GLS & Prob $>$ chi2 $=0.0000$ \\
GMM & Prob $>$ chi2 $=0.0060$ \\
\hline
\end{tabular}

Tabela 7 - Teste formal da simetria do efeito do Erro de Previsão sobre o Resultado Fiscal

Diferentemente de Chatagny e Soguel (2011), o efeito dos erros de previsão se mostrou assimétrico e com módulo do coeficiente maior no casos de subestimação da receita. Apesar das ocorrências de superestimação serem mais frequentes entre os estados 
brasileiros (339 observações contra 204 de subestimação), a subestimação se manifesta de forma mais significativa no resultado fiscal ex post em menores déficits/maiores superávits.

Estas são evidências favoráveis que as regras de procedimento orçamentário atuais são eficazes em reprimir a superestimação de receitas previstas no orçamento visando maiores gastos, mas são mais permissivas às situações de subestimação de receitas; estas últimas podem ser usadas visando censurar o apetite político por mais gastos, prevendo-os de forma conservadora na elaboração do orçamento. Espera-se que entre $25 \%$ e $50 \%$ da subestimação da receita na fase de elaboração e aprovação do orçamento se manifeste como melhora do resultado fiscal. 


\section{Secretários}

Nosso objetivo principal nesta seção é entender o possível poder explicativo que Secretários da Fazenda e Secretários do Planejamento nomeados por governadores possam ter sobre variáveis de política fiscal.

Considerando as peculiaridades do arcabouço institucional brasileiro, com a divisão da função de finance minister em duas pastas, neste capítulo são assumidas as seguintes premissas:

1. O Secretário da Fazenda é responsável pelo Resultado Fiscal do mesmo período em que se encontra na pasta;

2. O Secretário do Planejamento, responsável pela elaboração e envio das peças orçamentárias às Assembleias Legislativas, possui responsabilidade sobre a receita prevista na LOA (geralmente enviada até setembro do ano anterior ao ano fiscal em questão), e consequentemente, sobre o Erro de Previsão da receita observado no ano seguinte;

Neste capítulo usa-se o arcabouço teórico previamente estabelecido de condução prudencial da política fiscal em um ambiente de política fiscal fragmentada para compreender os possíveis efeitos das características dos Secretários da Fazenda sobre o Resultado Fiscal e das características dos Secretários do Planejamento (defasadas em um ano) sobre o Erro de Previsão. Em paralelo, analisa-se o poder explicativo de uma ampla seleção de variáveis de caráter político-eleitoral sobre o erro de previsão orçamentária, com intuito de explorar os possíveis usos oportunísticos da receita prevista no orçamento pelos agentes políticos responsáveis pelo orçamento.

\subsection{Secretários da Fazenda e Resultado Fiscal}

A Tabela 8 apresenta os resultados da estimação da equação 3.1 com adição das características dos secretários da Fazenda. Nas tabelas dessa seção serão usados "Sfaz"para características referentes a secretários da Fazenda e "Splan"para aquelas referentes a secretários do Planejamento.

Referindo às características do Secretário da Fazenda, observa-se que a única variável com coeficiente estatisticamente significativo, de forma robusta, é a experiência do secretário. A significância conjunta dos blocos de variáveis se encontra na Tabela $9^{11}$.

Secretários mais experientes (sendo a medida de experiência o número de anos

11 De fato, analisando a significância conjunta dos blocos observa-se que o bloco completo de características do secretário não possui poder explicativo sobre o resultado fiscal; tão somente o subconjunto de características profissionais, experiência no cargo inclusa, é estatisticamente significativo. 


\begin{tabular}{|c|c|c|c|c|c|c|}
\hline Variável Explicada = Resultado & (1) & $(2)$ & (3) & (4) & (5) & $(6)$ \\
\hline Erro & $\begin{array}{l}-0.0737 \\
(0.0942)\end{array}$ & $\begin{array}{l}-0.0868 \\
(0.0658)\end{array}$ & $\begin{array}{c}-0.0881 * * * \\
(0.0161)\end{array}$ & $\begin{array}{c}-0.110^{* * *} \\
(0.0178)\end{array}$ & $\begin{array}{c}-0.492^{* * *} \\
(0.0949)\end{array}$ & $\begin{array}{c}-0.979 * * * \\
(0.298)\end{array}$ \\
\hline Resultado (defasado) & $\begin{array}{c}0.524^{* *} \\
(0.212)\end{array}$ & $\begin{array}{c}0.469^{* *} \\
(0.205)\end{array}$ & $\begin{array}{c}0.560^{* * *} \\
(0.0378)\end{array}$ & $\begin{array}{c}0.493^{* * *} \\
(0.0401)\end{array}$ & & \\
\hline Crescimento & $\begin{array}{l}-1.472 \\
(1.382)\end{array}$ & $\begin{array}{l}-1.344 \\
(1.714)\end{array}$ & $\begin{array}{l}-1.528 \\
(0.942)\end{array}$ & $\begin{array}{c}-1.863^{*} \\
(0.955)\end{array}$ & $\begin{array}{c}-23.01^{* *} \\
(8.952)\end{array}$ & $\begin{array}{l}-27.29 \\
(20.25)\end{array}$ \\
\hline Sfaz_Sexo & $\begin{array}{l}-18.95 \\
(50.53)\end{array}$ & $\begin{array}{l}-24.99 \\
(49.76)\end{array}$ & $\begin{array}{c}-12.12 \\
(29.63)\end{array}$ & $\begin{array}{c}-20.86 \\
(31.78)\end{array}$ & $\begin{array}{c}394.3 \\
(339.2)\end{array}$ & $\begin{array}{c}1,102 \\
(887.6)\end{array}$ \\
\hline Sfaz_Exp & $\begin{array}{l}-5.285 \\
(3.335)\end{array}$ & $\begin{array}{l}-5.963^{*} \\
(3.195)\end{array}$ & $\begin{array}{c}-7.418^{* *} \\
(3.352)\end{array}$ & $\begin{array}{c}-8.103^{* *} \\
(3.426)\end{array}$ & $\begin{array}{c}56.95 \\
(48.75)\end{array}$ & $\begin{array}{c}63.03 \\
(99.99)\end{array}$ \\
\hline Sfaz_FuncPub & $\begin{array}{c}2.447 \\
(18.92)\end{array}$ & $\begin{array}{l}-8.289 \\
(21.56)\end{array}$ & $\begin{array}{c}5.290 \\
(15.84)\end{array}$ & $\begin{array}{c}3.664 \\
(17.09)\end{array}$ & $\begin{array}{c}24.93 \\
(164.3)\end{array}$ & $\begin{array}{l}-529.2 \\
(392.3)\end{array}$ \\
\hline Sfaz_TnSecretaria & $\begin{array}{l}-2.206 \\
(60.89)\end{array}$ & $\begin{array}{c}19.58 \\
(66.62)\end{array}$ & $\begin{array}{l}-33.34 \\
(23.20)\end{array}$ & $\begin{array}{l}-19.53 \\
(24.68)\end{array}$ & $\begin{array}{l}-432.4^{*} \\
(235.3)\end{array}$ & $\begin{array}{c}269.4 \\
(467.8)\end{array}$ \\
\hline Sfaz_Mestrado & $\begin{array}{l}-12.68 \\
(33.35)\end{array}$ & $\begin{array}{l}-19.75 \\
(34.77)\end{array}$ & $\begin{array}{c}0.535 \\
(24.42)\end{array}$ & $\begin{array}{l}-3.476 \\
(27.18)\end{array}$ & $\begin{array}{l}-369.9 \\
(306.4)\end{array}$ & $\begin{array}{c}79.96 \\
(688.2)\end{array}$ \\
\hline Sfaz_Doutorado & $\begin{array}{c}33.49 \\
(23.74)\end{array}$ & $\begin{array}{c}39.58 \\
(27.13)\end{array}$ & $\begin{array}{c}9.898 \\
(21.92)\end{array}$ & $\begin{array}{c}15.93 \\
(25.19)\end{array}$ & $\begin{array}{l}-121.7 \\
(210.1)\end{array}$ & $\begin{array}{l}-254.2 \\
(428.8)\end{array}$ \\
\hline Sfaz_Economia & $\begin{array}{l}-32.45 \\
(28.37)\end{array}$ & $\begin{array}{l}-13.98 \\
(29.91)\end{array}$ & $\begin{array}{l}-39.94^{*} \\
(21.98)\end{array}$ & $\begin{array}{l}-29.52 \\
(24.21)\end{array}$ & $\begin{array}{l}-18.63 \\
(233.6)\end{array}$ & $\begin{array}{c}731.0 \\
(474.4)\end{array}$ \\
\hline Sfaz_Direito & $\begin{array}{l}-8.372 \\
(25.96)\end{array}$ & $\begin{array}{l}-9.775 \\
(31.05)\end{array}$ & $\begin{array}{l}-15.99 \\
(20.50)\end{array}$ & $\begin{array}{l}-26.00 \\
(22.96)\end{array}$ & $\begin{array}{c}147.3 \\
(179.3)\end{array}$ & $\begin{array}{l}1,160^{* *} \\
(477.1)\end{array}$ \\
\hline Sfaz_Finanças & $\begin{array}{c}24.91 \\
(52.60)\end{array}$ & $\begin{array}{c}48.45 \\
(52.81)\end{array}$ & $\begin{array}{c}3.176 \\
(22.70)\end{array}$ & $\begin{array}{c}13.20 \\
(23.70)\end{array}$ & $\begin{array}{c}53.63 \\
(173.6)\end{array}$ & $\begin{array}{l}776.1^{*} \\
(407.5)\end{array}$ \\
\hline Sfaz_Engenharia & $\begin{array}{c}-54.34^{*} \\
(27.91)\end{array}$ & $\begin{array}{l}-40.89 \\
(28.09)\end{array}$ & $\begin{array}{l}-26.35 \\
(22.88)\end{array}$ & $\begin{array}{l}-26.91 \\
(25.26)\end{array}$ & $\begin{array}{c}-532.3^{* *} \\
(248.3)\end{array}$ & $\begin{array}{c}604.9 \\
(688.4)\end{array}$ \\
\hline Sfaz_Filiado & $\begin{array}{c}31.91 \\
(28.27)\end{array}$ & $\begin{array}{l}26.00 \\
(30.29)\end{array}$ & $\begin{array}{l}32.40^{*} \\
(19.13)\end{array}$ & $\begin{array}{c}17.41 \\
(21.87)\end{array}$ & $\begin{array}{c}83.33 \\
(214.0)\end{array}$ & $\begin{array}{l}-76.40 \\
(461.8)\end{array}$ \\
\hline Sfaz_PtdGovernador & $\begin{array}{l}-16.00 \\
(25.30)\end{array}$ & $\begin{array}{l}-14.95 \\
(24.16)\end{array}$ & $\begin{array}{l}-13.63 \\
(20.22)\end{array}$ & $\begin{array}{l}-16.64 \\
(22.15)\end{array}$ & $\begin{array}{l}-72.94 \\
(253.8)\end{array}$ & $\begin{array}{l}-111.9 \\
(620.6)\end{array}$ \\
\hline Constante & $\begin{array}{c}216.3^{* * *} \\
(48.65)\end{array}$ & $\begin{array}{c}783.3^{* *} \\
(319.6) \\
\end{array}$ & $\begin{array}{c}221.3^{* * *} \\
(42.80)\end{array}$ & $\begin{array}{c}974.9^{* * *} \\
(313.2)\end{array}$ & $\begin{array}{c}1,152^{* * *} \\
(248.6)\end{array}$ & $\begin{array}{l}11,158 \\
(6,956)\end{array}$ \\
\hline Estimador & OLS & OLS & GLS & GLS & GMM & GMM \\
\hline Controles Político-Institucionais & Não & Sim & Não & $\operatorname{Sim}$ & Não & Sim \\
\hline Observações & 588 & 548 & 588 & 548 & 595 & 555 \\
\hline
\end{tabular}

Tabela 8 - Regressão das características dos Secretários da Fazenda sobre o Resultado Fiscal

no cargo), em linha com os resultados de Feld e Schaltegger (2010), podem estar correlacionados com maiores superávits fiscais e menores gastos. Sob o arcabouço teórico de política fiscal em gabinetes fragmentados, o tempo de mandato e a experiência adquirida aumentaria a influência do secretário sobre seus colegas de gabinete e, portanto, a força relativa do Secretário da Fazenda sobre os spending ministers e diminuiria o problema de common pool do orçamento público. Além do aumento da influência, o maior conhecimento sobre a arrecadação das receitas e sobre os métodos usados por diferentes grupos de pressão para buscar uma ampliação dos gastos também poderia facilitar uma condução 'prudente' 


\begin{tabular}{lccc}
\hline \multicolumn{4}{c}{ Significância Conjunta - Secretário da Fazenda sobre Resultado Fiscal } \\
\hline \multicolumn{1}{c}{ Variáveis } & Chi2 & P-valor & \\
\hline Variáveis político-institucionais de controle & $\operatorname{chi} 2(10)=42.20$ & 0.000 & $* * *$ \\
Todas as características do Secretário & $\operatorname{chi} 2(11)=13.59$ & 0.256 & \\
Características profissionais & $\operatorname{chi} 2(3)=7.46$ & 0.059 & $*$ \\
Características acadêmicas & $\operatorname{chi} 2(5)=3.81$ & 0.577 & \\
Características partidárias & $\operatorname{chi} 2(3)=1.24$ & 0.744 & \\
\hline
\end{tabular}

Nota: *** indica significância estatística ao nível de $1 \%$, ** de $5 \%$ e * ao nível de $10 \%$.

Tabela 9 - Testes de Significância das características do Secretário da Fazenda sobre o Resultado Fiscal

ou 'austera' da política fiscal(MOESSINGER, 2014).

Observa-se que as regressões apresentam evidências diametralmente contrárias à estabelecida por esta hipótese da literatura, ou seja, os Secretários da Fazenda que possuem maior experiência no cargo estão relacionados com piores resultados fiscais, controlando pelo tempo em que o partido do governador passou no poder. Conclui-se que as hipóteses referentes ao efeito positivo que uma maior experiência no cargo teria sobre a força relativa do Secretário da Fazenda e à uma condução mais austera da política fiscal se mostram inválidas para o caso dos estados brasileiros.

Conjectura-se, então, que o tempo no cargo esteja relacionado a um efeito contrário, já observado no caso de políticos e governantes: maior tempo no comando da pasta pode se relacionar à um enfraquecimento das convicções quanto à condução prudencial da política fiscal, fortalecendo o ímpeto político de aumento de despesas e deterioração das contas públicas. A mudança do Secretário da Fazenda em períodos de 'vacas magras' pode estar vinculado à uma possível heurística dos governantes em que secretários novatos seriam mais rígidos quanto às demandas por maiores gastos de seus colegas, dando suporte a essa suposição. Com o tempo, a proximidade pessoal e política na administração pública poderia aumentar a influência relativa dos spending ministers. Deste modo, o comportamento de seleção dos governantes pode corroborar a validade do coeficiente negativo da experiência do Secretário da Fazenda sobre o resultado fiscal.

\subsection{Secretários do Planejamento e Erro de Previsão}

As Tabelas 10 e 11 apresentam os resultados da estimação da equação 3.2 com os Erros de Previsão explicados pelas características dos Secretários do Planejamento (defasado em um período) e variáveis político-institucionais ${ }^{12}$.

12 Opta-se por utilizar as variáveis de controle político que são determinadas eleitoralmente defasadas em um períodos, visto que consideramos os governadores e deputados estaduais em exercício no período de elaboração do orçamento mais relevantes do que os que estão em exercício na fase de execução do 


\begin{tabular}{|c|c|c|c|c|}
\hline Variável Explicada = Erro & (1) & $(2)$ & $(3)$ & $(4)$ \\
\hline Crescimento & $\begin{array}{c}-6.555^{* *} \\
(3.110)\end{array}$ & $\begin{array}{c}-7.271^{*} \\
(3.755)\end{array}$ & $\begin{array}{c}-5.312^{* * *} \\
(1.601)\end{array}$ & $\begin{array}{c}-4.811^{* * *} \\
(1.848)\end{array}$ \\
\hline ÍndiceAlesina (defasado) & $\begin{array}{c}-21.61^{* *} \\
(9.458)\end{array}$ & $\begin{array}{c}-18.47^{* *} \\
(9.337)\end{array}$ & $\begin{array}{c}-21.03^{* *} \\
(8.582)\end{array}$ & $\begin{array}{c}-19.55^{* *} \\
(8.639)\end{array}$ \\
\hline Splan_Sexo & $\begin{array}{c}35.79 \\
(95.98)\end{array}$ & $\begin{array}{c}66.62 \\
(117.5)\end{array}$ & $\begin{array}{c}60.53 \\
(59.81)\end{array}$ & $\begin{array}{c}139.1^{* *} \\
(68.03)\end{array}$ \\
\hline Splan_Exp & $\begin{array}{l}-20.30^{*} \\
(10.87)\end{array}$ & $\begin{array}{l}-14.77 \\
(11.22)\end{array}$ & $\begin{array}{c}-15.57^{* *} \\
(6.748)\end{array}$ & $\begin{array}{c}-13.78^{* *} \\
(6.893)\end{array}$ \\
\hline Splan_FuncPub & $\begin{array}{l}-25.96 \\
(41.23)\end{array}$ & $\begin{array}{c}7.985 \\
(46.32)\end{array}$ & $\begin{array}{l}-27.56 \\
(34.83)\end{array}$ & $\begin{array}{l}-32.17 \\
(35.56)\end{array}$ \\
\hline Splan_TnSecretaria & $\begin{array}{c}178.9 \\
(122.7)\end{array}$ & $\begin{array}{c}114.0 \\
(121.3)\end{array}$ & $\begin{array}{c}131.8^{* *} \\
(60.03)\end{array}$ & $\begin{array}{c}96.20 \\
(60.61)\end{array}$ \\
\hline Splan_Mestrado & $\begin{array}{c}127.9 \\
(81.34)\end{array}$ & $\begin{array}{l}183.3^{* *} \\
(87.80)\end{array}$ & $\begin{array}{c}55.25 \\
(57.10)\end{array}$ & $\begin{array}{c}89.96 \\
(57.95)\end{array}$ \\
\hline Splan_Doutorado & $\begin{array}{c}-130.7^{*} \\
(72.04)\end{array}$ & $\begin{array}{c}-179.3^{* *} \\
(72.51)\end{array}$ & $\begin{array}{l}-59.49 \\
(50.70)\end{array}$ & $\begin{array}{l}-75.21 \\
(52.35)\end{array}$ \\
\hline Splan_Economia & $\begin{array}{l}-62.81 \\
(48.68)\end{array}$ & $\begin{array}{l}-54.95 \\
(56.32)\end{array}$ & $\begin{array}{l}-63.86 \\
(41.01)\end{array}$ & $\begin{array}{l}-66.55 \\
(42.30)\end{array}$ \\
\hline Splan_Direito & $\begin{array}{l}-96.25 \\
(65.48)\end{array}$ & $\begin{array}{l}-77.25 \\
(67.17)\end{array}$ & $\begin{array}{c}-86.84^{*} \\
(49.01)\end{array}$ & $\begin{array}{l}-73.20 \\
(49.83)\end{array}$ \\
\hline Splan_Finanças & $\begin{array}{l}-111.0 \\
(75.92)\end{array}$ & $\begin{array}{l}-125.7^{*} \\
(72.57)\end{array}$ & $\begin{array}{c}-161.4^{* * *} \\
(50.91)\end{array}$ & $\begin{array}{c}-176.6^{* * * *} \\
(53.30)\end{array}$ \\
\hline Splan_Engenharia & $\begin{array}{l}-81.46^{*} \\
(45.00)\end{array}$ & $\begin{array}{l}-81.15 \\
(57.48)\end{array}$ & $\begin{array}{c}-90.70^{* *} \\
(42.84)\end{array}$ & $\begin{array}{c}-108.9^{* *} \\
(44.78)\end{array}$ \\
\hline Splan_Filiado & $\begin{array}{l}-23.05 \\
(50.76)\end{array}$ & $\begin{array}{l}-45.60 \\
(70.92)\end{array}$ & $\begin{array}{l}-10.37 \\
(34.56)\end{array}$ & $\begin{array}{l}-19.15 \\
(37.32)\end{array}$ \\
\hline Splan_PtdGovernador & $\begin{array}{l}-43.72 \\
(60.13)\end{array}$ & $\begin{array}{l}-38.23 \\
(65.58)\end{array}$ & $\begin{array}{l}-5.847 \\
(36.82)\end{array}$ & $\begin{array}{l}-8.591 \\
(39.02)\end{array}$ \\
\hline Estimador & OLS & OLS & GLS & GLS \\
\hline Controles Político-Institucionais & Não & Sim & Não & Sim \\
\hline Observações & 591 & 540 & 591 & 540 \\
\hline
\end{tabular}

Nota: $* * *$ indica significância estatística ao nível de $1 \%, * *$ de $5 \%$ e * ao nível de $10 \%$.

Tabela 10 - Regressão do Erro de Previsão sobre o Resultado Fiscal

Como esperado, nota-se que o desvio orçamentário é sensível ao crescimento econômico, devido à sensibilidade da receita efetiva à produção. Notavelmente, o índice de qualidade orçamentária IndiceAlesina $a_{i t-1}$ teve coeficientes significativos e negativos. Dessa forma, como esperado, a qualidade das regras de procedimento orçamentário se mostram correlacionadas à redução da sobre-estimação da receita no orçamento e maior prudência na condução orçamentária. Considerando a metodologia de Leal (2020), baseada em Alesina et al. (1999), esta diferença provavelmente se manifesta através do segundo

orçamento. Empiricamente, porém, as duas escolhas não se mostraram significativamente distintas. 


\begin{tabular}{|c|c|c|c|c|}
\hline Variável Explicada = Erro & $(1)$ & $(2)$ & $(3)$ & $(4)$ \\
\hline Transferências & & $\begin{array}{l}-98.01 \\
(223.8)\end{array}$ & & $\begin{array}{l}-27.98 \\
(135.4)\end{array}$ \\
\hline GovExperiência & & $\begin{array}{c}-5.703 \\
(10.50)\end{array}$ & & $\begin{array}{l}-2.706 \\
(5.314)\end{array}$ \\
\hline Coligação & & $\begin{array}{l}-4.032 \\
(6.084)\end{array}$ & & $\begin{array}{c}-0.507 \\
(4.396)\end{array}$ \\
\hline Preeleitoral & & $\begin{array}{c}-184.0^{* *} \\
(73.25)\end{array}$ & & $\begin{array}{c}-135.0^{* *} \\
(64.61)\end{array}$ \\
\hline Eleitoral & & $\begin{array}{l}-35.59 \\
(34.30)\end{array}$ & & $\begin{array}{l}-144.0^{*} \\
(74.42)\end{array}$ \\
\hline Poseleitoral & & $\begin{array}{c}1.698 \\
(30.42)\end{array}$ & & $\begin{array}{c}149.9^{* *} \\
(63.19)\end{array}$ \\
\hline Concordância & & $\begin{array}{l}-9.149 \\
(33.67)\end{array}$ & & $\begin{array}{l}-18.32 \\
(24.14)\end{array}$ \\
\hline Concorrência & & $\begin{array}{c}6.616 \\
(8.326)\end{array}$ & & $\begin{array}{c}1.753 \\
(4.299)\end{array}$ \\
\hline FracLegis & & $\begin{array}{l}-154.7 \\
(864.4)\end{array}$ & & $\begin{array}{l}1,165^{*} \\
(601.7)\end{array}$ \\
\hline Constante & $\begin{array}{c}1,432^{* *} \\
(601.3)\end{array}$ & $\begin{array}{c}1,504 \\
(1,041)\end{array}$ & $\begin{array}{c}1,591 * * * \\
(585.7)\end{array}$ & $\begin{array}{c}600.2 \\
(814.3)\end{array}$ \\
\hline Estimador & OLS & OLS & GLS & GLS \\
\hline Controles Político-Institucionais & Não & Sim & Não & Sim \\
\hline Observações & 591 & 540 & 591 & 540 \\
\hline
\end{tabular}

Tabela 11 - Regressão do Erro de Previsão sobre o Resultado Fiscal

eixo do questionário, que trata de regras de procedimento que concedem ao Executivo mais poder em relação ao Legislativo na fase de aprovação do orçamento.

As demais variáveis políticas de controle se mostraram pouco significativas, quando expostas à diferentes especificações.

As variáveis binárias referentes ao ciclo eleitoral se mostram significativas, apesar de apresentarem resultados de difícil interpretação, considerando a literatura tradicional de ciclos eleitorais. De forma robusta às especificações alternativas, os anos pré-eleitorais e eleitorais se mostram relacionados a um menor comportamento de superestimação. Diferentemente, os anos após as eleições gerais são marcados por uma estimação menos prudente das receitas.

É possível conjecturar que os menores erros orçamentários em período eleitoral resultam da necessidade do governante atual de manter sua credibilidade perante a sociedade em um período em que a administração pública está sob escrutínio. Após as eleições, as previsões exageradamente otimistas das receitas seguiriam seu curso, com 


\begin{tabular}{lccc}
\hline \multicolumn{4}{c}{ Significância Conjunta - Secretário do Planejamento sobre Erro } \\
\hline \multicolumn{1}{c}{ Variáveis } & Chi2 & P-valor & \\
\hline Variáveis político-institucionais de controle & $\operatorname{chi} 2(10)=20.98$ & 0.021 & $* *$ \\
Todas as características do Secretário & $\operatorname{chi} 2(11)=25.99$ & 0.006 & $* * *$ \\
Características profissionais & $\operatorname{chi} 2(3)=7.12$ & 0.068 & $*$ \\
Características acadêmicas & $\operatorname{chi} 2(5)=13,35$ & 0.020 & $* *$ \\
Características partidárias & $\operatorname{chi2}(3)=2.18$ & 0.537 & \\
\hline
\end{tabular}

Nota: *** indica significância estatística ao nível de $1 \%, * *$ de $5 \%$ e * ao nível de $10 \%$.

Tabela 12 - Testes de Significância das características do Secretário do Planejamento sobre o Erro de Previsão

intenção de adotar uma política fiscal mais expansiva nos primeiro e segundo anos de governo.

São realizados testes de significância conjunta das variáveis de interesse e controle sobre a variável dependente. A matriz completa de variáveis político-institucionais de controle se mostrou estatisticamente significativa, assim como a matriz completa de características do Secretário do Planejamento, como visto na Tabela $12^{13}$. Considerando os sub-blocos de características dos Secretários, somente as características de filiação partidária se mostraram estatisticamente não-significativas.

Poderia-se argumentar, inicialmente, que existem problemas decorrentes de causalidade reversa à medida que altos erros orçamentários passados ou situação econômica adversa poderiam influenciar a escolha do governador pelo secretário do Planejamento.

Então, cabe analisar o efeito de um possível viés de auto-seleção: por exemplo, em épocas de receitas frustradas e más condições econômicas, um governante pode estar mais propenso a escolher um Secretário do Planejamento com melhor formação acadêmica, ou que já trabalhasse na Secretaria e desta forma possua maior conhecimento da burocracia da pasta. São elaborados testes-t de Student para estudar se há diferenças significativas entre as características do Secretários do Planejamento um ano após períodos de recessão econômica dos estados ou alta superestimação das receitas. Não são encontradas diferenças significativas nas características dos incumbentes da pasta do Planejamento. Argumenta-se, devido ao fato de que esta pasta é tipicamente responsável pelos planos estratégicos de médio e longo prazo da gestão pública, que a escolha dos governantes por estes secretários não seja fortemente influenciada por questões conjunturais.

Ponderando o caráter dual do erro de previsão, considerando o seu aspecto proposital e seu aspecto acidental, analisa-se a relevância da experiência do Secretário do Planejamento

13 Como forma de fortalecer os resultados, foram feitas regressões com os Secretários do Planejamento no cargo no ano corrente ao qual o exercício fiscal se refere. Estas características do Secretário do Planejamento em período corrente se mostraram conjuntamente não-significativas. 
sobre este. Secretários mais experientes (sendo a medida de experiência o número de anos no cargo, isto é, por quantas fases de planejamento orçamentário este secretário já passou) aprenderiam com os desvios 'técnicos' passados e, considerando previsões eficientes, cometeriam menos erros 'acidentais' nas previsões orçamentárias. O principal interesse continua sendo a manipulação proposital da previsão de receita contida no orçamento, e para tal, analogamente à literatura de política fiscal em gabinetes fragmentados, considerase que o tempo de mandato e a experiência adquirida aumentem a influência sobre seus colegas (e que aumente também o conhecimento sobre as estratégias políticas destes) e, portanto, a força relativa do Secretário do Planejamento sobre os spending ministers e diminua a superestimação da receita buscando ganhos políticos.

As regressões apresentam evidências favoráveis à hipótese principal sobre a 'força' do Secretário do Planejamento: secretários que já possuem maior experiência no cargo estão relacionados com uma menor tendência de superestimar as receitas na elaboração do orçamento, mesmo controlando pelo tempo em que o partido do governador passou no poder. Considerando que esta condução prudencial das previsões orçamentárias esteja vinculada a menores déficits ex post, este resultado encontra consistência com o trabalho de Moessinger (2014), em que finance ministers mais experientes estão relacionados a menores aumentos na dívida, e Jochimsen e Thomasius (2014), em que ministros mais experientes estão associados com déficits menores ${ }^{14}$.

De modo análogo, estuda-se o efeito da formação acadêmica do Secretário sobre a condução de uma política orçamentária prudencial, de menor superestimação da receita. Assume-se que secretários com formação acadêmica mais extensa possuem maior domínio das regras procedimentais do processo orçamentário, melhor aparato técnico-estatístico, assim como um maior conhecimento da relevância do contexto macroeconômico sobre as previsões orçamentárias. Além da maior capacidade técnica, a formação como mestre ou doutor poderia aumentar a influência destes sobre o comportamento dos outros secretários do gabinete.

Observando os resultados da regressão, a formação como mestre está correlacionada com maiores erros de previsão, enquanto a formação como doutor se relaciona com menores erro, obtendo, portanto, um efeito não-linear da extensão da formação acadêmica sobre o comportamento de subestimação da receita.

Em linha com os trabalhos de Jochimsen e Thomasius (2014) e Moessinger (2014), considera-se como relevante a formação prévia do secretário em cursos de Ciências Econômicas, Administração, Contabilidade e Gestão; estes podem ser atuar como bons proxies da experiência prévia dos secretários com finanças, negócios e orçamento, e podem estar

14 Considerando as estimações alternativas, os coeficientes se mostram consistentes, mas o nível de significância estatística apresenta variação a depender do método de estimação e das variáveis de controle presentes. Notavelmente, a inclusão da experiência do partido do governador como controle diminui drasticamente a significância estatística da experiência do secretário em algumas especificações. 
relacionados com maior prudência na condução da política fiscal. Em especial, poderia se esperar que a formação em economia esteja relacionada com um maior conhecimento das consequências de longo prazo de trajetórias insustentáveis de dívida pública.

Observa-se que a formação em Economia ou Direito apresenta baixa significância estatística relativamente à base de comparação de Secretários com outras formações ou formação desconhecida, mas com coeficientes consistentemente negativos. Já históricos acadêmicos em finanças (Contabilidade, Administração ou Gestão) ou em alguma disciplina da Engenharia se mostraram significativos estatisticamente e relacionados com menor superestimação / maior subestimação das receitas.

Desta forma, tem-se evidências a favor de que a área de formação importa; mas a faculdade de economia pode ter um efeito ambivalente sobre a prudência na condução do orçamento, enquanto outras formações em finanças possuem um efeito mais claro e robusto às diferentes especificações. Uma possível explicação para a correlação ambígua entre a formação em ciências econômicas e uma condução prudencial das previsões orçamentárias é que a diversidade de opiniões no debate econômico brasileiro sobre o valor de políticas fiscais expansionistas faz com que haja uma distribuição relativamente equilibrada entre economistas mais austeros ou mais prudentes em relação à média. Em contrapartida, profissionais formados na área de Contabilidade, Administração ou Gestão (podendo incluir as Engenharias) poderiam ter, em média, uma visão mais direta, vinculada ao setor empresarial, do valor em manter as finanças em dia no curto prazo.

Seguindo os trabalhos de Feld e Schaltegger (2010) e Jochimsen e Nuscheler (2011), testa-se a possibilidade do secretário ser filiado ao mesmo partido do governador ser um indicativo de sua força relativa no gabinete; Secretários do Planejamento filiados ao mesmo partido do governador seriam relacionados com um menor viés otimista no orçamento, à medida que estes seriam mais próximos do governador e de sua base política e menos influenciados pelo restante do gabinete. Observando os coeficientes relacionados à filiação partidária do Secretário, temos que ser filiado a um partido e especialmente, ser filiado ao mesmo partido do governador não se mostram estatisticamente significativos em explicar o desvio orçamentário. Desse modo, a hipótese assumida é, a princípio, rejeitada; não nos parece que a filiação ao mesmo partido do governador seja um real indicador da proximidade pessoal do secretário, ou que essa proximidade se mostre relevante na condução das previsões orçamentárias.

Novamente, dadas as dificuldades de definir ideologia são feitas novas estimações sem a filiação partidária do Secretário do Planejamento e os resultados não se alteram como mostrado na Tabela 25 do Apêndice C. 


\section{Conclusões}

Esta dissertação tem dois objetivos. O primeiro é avaliar o papel desempenhado pelos erros de previsão de receita sobre os resultados fiscais dos estados brasileiros no período 1994-2018. O segundo é entender a possível influência das características pessoais e profissionais dos secretários da Fazenda e do Planejamento sobre a condução da política fiscal. As características dos secretários da Fazenda afetariam diretamente os resultados fiscais, uma vez que a pasta da Fazenda é responsável pela saúde das contas públicas e a sustentabilidade da dívida pública. As características dos secretários de Planejamento, por sua vez, afetariam os resultados fiscais somente através dos erros de previsão. Se os secretário do Planejamento são responsáveis pela elaboração das peças orçamentárias e pelas previsões nelas contidas, eles podem a usar os erros de previsão como um instrumento oculto de política fiscal.

Usando-se uma base de dados em painel referente às 27 unidades federativas brasileiras no período 1995-2018, encontra-se evidências de que os erros de previsão orçamentária possuem um efeito significativo e negativo sobre o resultado fiscal, de modo que para cada real per capita de sub-estimação da receita na fase de planejamento do orçamento, espera-se que um resultado fiscal melhor entre 0,25 e 0,50 reais per capita. Sob outra ótica, entre $50 \%$ e $75 \%$ do erro de previsão de receita na fase do planejamento do orçamento é corrigida no decorrer do ano fiscal, através dos mecanismos discricionários presentes na fase de execução do orçamento. Este trabalho traz, assim, uma contribuição para a literatura ao demonstrar que os resultados de Chatagny e Soguel (2011)) são válidos, em diferente grau de intensidade, em contextos institucionais distintos.

Seria, portanto, a subestimação de receitas defensável como mecanismo de diminuição da tendência deficitária dos estados brasileiros? Em geral, não parece ser este o caso. Se somente entre $25 \%$ e $50 \%$ da subestimação se concretiza como melhora no balanço fiscal, os $50 \%$ a $75 \%$ restante dos recursos são extraídos do debate democrático do orçamento, ocorrido em ritos pré-estabelecidos e fiscalizado pela sociedade através de seus representantes na Assembleia Legislativa. Estes recursos podem ser alocados de formas ainda mais distante dos interesses dos eleitores, ou até mesmo subvertidos por processos corruptos, em situações de maior deterioração institucional (CHATAGNY; SOGUEL, 2011).

Observa-se empiricamente que a única variável referente aos Secretários da Fazenda importante para explicar o resultado fiscal é a quantidade de anos no cargo. Secretários da Fazenda mais experientes estão correlacionados com piores resultados fiscais. Conjectura-se que Secretários da Fazenda nomeados com o ímpeto de conduzir a política fiscal de forma 
mais austera se corrompam às preferências políticas de curto prazo por gastos dos outros secretários com o tempo no cargo.

Estima-se que Secretários do Planejamento mais experientes no cargo, com doutorado e formação em finanças ou engenharia estão correlacionados com menor super estimação das receitas. Tais secretários, considerando os erros de previsão orçamentária como um canal de atuação sobre o resultado fiscal, podem ser mais propensos a uma condução mais austera ou prudencial da política fiscal, enfrentando para isso o maior apetite de gastos dos outros membros do gabinete.

O poder explicativo das características dos secretários sobre o planejamento e condução do orçamento é um argumento favorável a uma mudança institucional a favor de previsões orçamentárias feitas por algum tipo de 'autoridade fiscal independente', nos moldes do trabalho seminal de Jonung e Larch (2006). Esta previsão seria politicamente independente, regular, pública e aberta ao debate e escrutínio de especialistas, e de uso obrigatório na elaboração das peças orçamentárias. O desempenho do método de previsão seria julgado em médio e longo prazo, com estabelecimento de mecanismo de punição aos diretores da autoridade.

Julga-se que tal arcabouço poderia trazer ganhos sociais à transparência da política fiscal e na participação democrática, visto que os governantes e demais autoridades responsáveis pela política fiscal seriam obrigados a revelar melhor suas reais preferências quanto ao resultado fiscal, em vez de 'mascará-las' sob a justificativa de frustração de expectativas macroeconômicas. Na época de publicação do trabalho, Holanda, Bélgica e Áustria já possuíam agências formalmente independentes (apesar da dependência de fundos governamentais), e estas não demonstravam viés sistemático em suas previsões orçamentárias (Jonung e Larch (2006)).

Trabalhos futuros podem contribuir para compreensão do efeito das características pessoais, profissionais e partidárias dos Secretários da Fazenda e Secretários do Planejamento sobre outras variáveis de política fiscal; também espera-se o uso do método para a exploração de efeitos que outros secretários possam ter sobre o orçamento. Por exemplo, seria o partido de filiação do Secretário da Educação de cada estado relevante para a alocação de maiores fatias do orçamento em sua pasta?

O viés deficitário e as limitações do processo orçamentário dos entes federativos brasileiros também podem ser melhor compreendidos por uma investigação mais profunda de quais são os determinantes político-econômicos da subestimação e da sobre-estimação da receita no processo orçamentário. Avanços importantes também podem ser feitos para auferir como a composição do gasto público se altera na presença destes desvios orçamentários; tal análise poderia trazer evidências de uma possível assimetria entre os gastos 'extras' executados na presença de receitas 'inesperadas' e quais são os primeiros gastos a serem cortados quando a expectativa de arrecadação é frustrada. 


\section{Referências}

ALESINA, A. et al. Budget institutions and fiscal performance in latin america. Journal of development Economics, Elsevier, v. 59, n. 2, p. 253-273, 1999.

ALESINA, A.; PEROTTI, R. Budget deficits and budget institutions. [S.l.], 1996.

ARELLANO, M.; BOVER, O. Another look at the instrumental variable estimation of error-components models. Journal of econometrics, Elsevier, v. 68, n. 1, p. 29-51, 1995.

BALTAGI, B. H. Forecasting with panel data. Journal of forecasting, Wiley Online Library, v. 27, n. 2, p. 153-173, 2008.

BERTRAND, M.; SCHOAR, A. Managing with style: The effect of managers on firm policies. The Quarterly journal of economics, Oxford University Press, v. 118, n. 4, p. 1169-1208, 2003.

BISCHOFF, I.; GOHOUT, W. The political economy of tax projections. International Tax and Public Finance, Springer, v. 17, n. 2, p. 133-150, 2010.

BLUNDELL, R.; BOND, S. Initial conditions and moment restrictions in dynamic panel data models. Journal of econometrics, Elsevier, v. 87, n. 1, p. 115-143, 1998.

BRASIL. Constituição. Brasília (DF), 1988.

BRASIL. Lei complementar $n^{\circ}$ 101, de 4 de maio de 2000. Estabelece normas de finanças públicas voltadas para a responsabilidade na gestão fiscal e dá outras providências. Brasília (DF): Gráfica do Senado, 2000.

BROLLO, F.; TROIANO, U. What happens when a woman wins a election? evidence from close races in brazil. Journal of Development Economics, v. 122, p. 28-45, 2016.

BUCHANAN, J. M. The theory of public finance. [S.1.]: JSTOR, 1960.

BUCHANAN, J. M.; TULLOCK, G. The calculus of consent. [S.l.]: University of Michigan press Ann Arbor, 1962. v. 3.

CHATAGNY, F. Incentive effects of fiscal rules on the finance minister's behaviour: Evidence from revenue projections in swiss cantons. KOF Working Papers, 2013.

CHATAGNY, F.; SOGUEL, N. C. Sses 2011 rationality and determinants of tax revenue forecasting errors: Evidence from swiss cantons. 2011.

COUTURE, J.; IMBEAU, L. M. Do governments manipulate their revenue forecasts? budget speech and budget outcomes in the canadian provinces. In: Do They Walk Like They Talk? [S.l.]: Springer, 2009. p. 155-166.

DEBRUN, X. et al. Tied to the mast? national fiscal rules in the european union. Economic Policy, v. 23, n. 54, p. 297-362, 2008.

DREHER, A. et al. The impact of political leaders' profession and education on reforms. Journal of comparative economics, Elsevier, v. 37, n. 1, p. 169-193, 2009. 
FARVAQUE, E.; STANEK, P.; HAMMADOU, H. Selecting your inflation targeters: Background and performance of monetary policy committee members. German Economic Review, De Gruyter, v. 12, n. 2, p. 223-238, 2011.

FAZENDA, M. da. Manual da Receita Nacional. [S.l.]: STN/Coordenação-Geral de Contabilidade, 2008.

FELD, L. P.; KIRCHGÄSSNER, G. Direct democracy, political culture, and the outcome of economic policy: a report on the swiss experience. European Journal of Political Economy, Elsevier, v. 16, n. 2, p. 287-306, 2000.

FELD, L. P.; KIRCHGÄSSNER, G. Does direct democracy reduce public debt evidence from swiss municipalities. Public Choice, Springer, v. 109, n. 3, p. 347-370, 2001.

FELD, L. P.; SCHALTEGGER, C. A. Political stability and fiscal policy: time series evidence for the swiss federal level since 1849. Public Choice, Springer, v. 144, n. 3-4, p. 505-534, 2010.

GOEMINNE, S.; GEYS, B.; SMOLDERS, C. Political fragmentation and projected tax revenues: evidence from flemish municipalities. International Tax and Public Finance, Springer, v. 15, n. 3, p. 297-315, 2008.

GÖHLMANN, S.; VAUBEL, R. The educational and occupational background of central bankers and its effect on inflation: An empirical analysis. European Economic Review, Elsevier, v. 51, n. 4, p. 925-941, 2007.

HALLERBERG, M.; STRAUCH, R. R.; HAGEN, J. V. Fiscal governance in Europe. [S.l.]: Cambridge University Press, 2009.

JOCHIMSEN, B.; NUSCHELER, R. The political economy of the german länder deficits: weak governments meet strong finance ministers. Applied Economics, Taylor \& Francis, v. 43, n. 19, p. 2399-2415, 2011.

JOCHIMSEN, B.; THOMASIUS, S. The perfect finance minister: Whom to appoint as finance minister to balance the budget. European Journal of Political Economy, Elsevier, v. 34, p. 390-408, 2014.

JONES, B. F.; OLKEN, B. A. Do leaders matter? national leadership and growth since world war ii. The Quarterly Journal of Economics, MIT Press, v. 120, n. 3, p. 835-864, 2005 .

JONUNG, L.; LARCH, M. Improving fiscal policy in the eu: the case for independent forecasts. Economic Policy, Oxford University Press, v. 21, n. 47, p. 492-534, 2006.

JÚNIOR, C. Z.; POWER, T. J. Fragmentation without cleavages? ideology, policy preferences, and political polarization in brazil. 2018.

LEAL, R. Instituições orçamentárias e seus impactos sobre o resultado fiscal dos estados brasileiros. 2020.

MOCAN, H. N.; AZAD, S. Accuracy and rationality of state general fund revenue forecasts: Evidence from panel data. International journal of Forecasting, Elsevier, v. 11, n. 3, p. 417-427, 1995. 
MOESSINGER, M.-D. Do the personal characteristics of finance ministers affect changes in public debt? Public choice, Springer, v. 161, n. 1-2, p. 183-207, 2014.

NICKELL, S. Biases in dynamic models with fixed effects. Econometrica: Journal of the econometric society, JSTOR, p. 1417-1426, 1981.

PEROTTI, R.; KONTOPOULOS, Y. Fragmented fiscal policy. Journal of Public Economics, Elsevier, v. 86, n. 2, p. 191-222, 2002.

PIZA, E. C. d. Política fiscal, previsões orçamentárias e os determinantes dos desvios de execução no Brasil. Tese (Doutorado) — Universidade de São Paulo, 2016.

PLANEJAMENTO, O. e. G. Secretaria de Orçamento Federal; Ministério do. Diagnóstico da Área Orçamentária dos Estados Brasileiros. 2011.

PLOEG, F. van der. Political economy of prudent budgetary policy. International Tax and Public Finance, Springer, v. 17, n. 3, p. 295-314, 2010.

POLITICA, D. Metodologia. 2018. < http://datapolitica.com.br/eleicao/metodologia. html>. Accessed: 2020-04-20.

POLITICA, D. Quociente partidário. 2018. < http://www.tse.jus.br/eleitor/glossario/ termos/quociente-partidario $>$. Accessed: 2020-04-20.

REZENDE, F. A reforma orçamentária e a eficiência fiscal. [S.l.], 2009.

RODRIGUES, L. M. Partidos, ideologia e composição social. Revista Brasileira de Ciências Sociais, SciELO Brasil, v. 17, n. 48, p. 31-47, 2002.

SHAH, A. Budgeting and budgetary institutions. [S.1.]: The World Bank, 2007.

VELASCO, A. Debts and deficits with fragmented fiscal policymaking. Journal of Public Economics, Elsevier, v. 76, n. 1, p. 105-125, 2000.

VOLKERINK, B.; HAAN, J. D. Fragmented government effects on fiscal policy: New evidence. Public choice, Springer, v. 109, n. 3-4, p. 221-242, 2001.

VON HAGEN, J.; HARDEN, I. J. Budget processes and commitment to fiscal discipline. European Economic Review, Elsevier, v. 39, n. 3-4, p. 771-779, 1995. 


\section{APÊNDICE A - Observações de Secretários}

Neste apêndice são descritas as observações de Secretários do Planejamento e da Fazenda distintos. Tem-se o intuito de, sem incluir os nomes dos incumbentes, ilustrar quantos secretários diferentes foram observados em cada pasta de cada estado no período de 1995-2018, e quantos destes apresentam as características que foram utilizados nos modelos de dados em painel. Como as variáveis de experiência variam temporalmente para cada secretário, opta-se aqui pelo uso do conceito de mandato médio para cada estado, aqui compreendido como a média do número total de anos que os secretários passaram no cargo. Na Tabela 13 são apresentados o número de secretários em cada estado, tempo no cargo e filiação partidária, enquanto na Tabela 14 encontram-se as observações por nível de escolaridade. As Tabelas 15 e 16 demonstram a quantidade de observações por curso superior de formação dos Secretários do Planejamento e Secretários da Fazenda, respectivamente. 


\begin{tabular}{|c|c|c|c|c|c|c|c|c|}
\hline & \multicolumn{4}{|c|}{ Secretários do Planejamento } & \multicolumn{4}{|c|}{ Secretários da Fazenda } \\
\hline & Secretários & Mandato & Partido & Esquerda & Secretários & Mandato & Partido & Esquerda \\
\hline $\mathrm{AC}$ & 3 & 7,6 & 2 & 2 & 6 & 2,7 & 4 & 2 \\
\hline $\mathrm{AL}$ & 11 & 2,2 & 7 & 3 & 9 & 2,0 & 2 & 2 \\
\hline $\mathrm{AM}$ & 12 & 1,9 & 1 & 0 & 5 & 4,5 & 0 & 0 \\
\hline $\mathrm{AP}$ & 8 & 2,5 & 5 & 3 & 3 & 4,7 & 2 & 1 \\
\hline $\mathrm{BA}$ & 9 & 2,6 & 9 & 4 & 6 & 3,9 & 1 & 1 \\
\hline $\mathrm{CE}$ & 9 & 2,5 & 5 & 1 & 4 & 3,8 & 4 & 1 \\
\hline $\mathrm{DF}$ & 7 & 2,4 & 2 & 1 & 7 & 2,4 & 2 & 1 \\
\hline ES & 13 & 1,7 & 9 & 6 & 10 & 2,2 & 5 & 1 \\
\hline GO & 7 & 3,7 & 6 & 0 & 13 & 1,9 & 6 & 0 \\
\hline MA & 9 & 2,7 & 4 & 3 & 5 & 5,0 & 2 & 0 \\
\hline MG & 8 & 3,0 & 4 & 2 & 6 & 4,2 & 1 & 0 \\
\hline MS & 11 & 2,0 & 9 & 5 & 10 & 2,2 & 3 & 2 \\
\hline MT & 7 & 2,8 & 2 & 0 & 9 & 2,6 & 1 & 0 \\
\hline $\mathrm{PA}$ & 7 & 3,4 & 3 & 2 & 9 & 2,6 & 2 & 1 \\
\hline $\mathrm{PB}$ & 9 & 2,4 & 5 & 2 & 8 & 2,7 & 2 & 1 \\
\hline $\mathrm{PE}$ & 10 & 2,4 & 5 & 3 & 10 & 2,4 & 3 & 2 \\
\hline PI & 8 & 2,6 & 4 & 2 & 6 & 2,7 & 3 & 2 \\
\hline $\mathrm{PR}$ & 13 & 1,4 & 8 & 2 & 7 & 3,4 & 3 & 0 \\
\hline RJ & 9 & 2,2 & 5 & 2 & 12 & 1,8 & 5 & 1 \\
\hline $\mathrm{RN}$ & 6 & 3,3 & 2 & 1 & 6 & 3,2 & 2 & 0 \\
\hline $\mathrm{RO}$ & 8 & 2,8 & 5 & 0 & 8 & 2,8 & 4 & 1 \\
\hline $\mathrm{RR}$ & 7 & 3,2 & 2 & 0 & 11 & 2,2 & 3 & 1 \\
\hline $\mathrm{RS}$ & 10 & 2,0 & 4 & 3 & 7 & 2,4 & 5 & 2 \\
\hline $\mathrm{SC}$ & 14 & 1,5 & 6 & 3 & 15 & 1,3 & 8 & 1 \\
\hline $\mathrm{SE}$ & 9 & 2,6 & 6 & 1 & 9 & 3,0 & 4 & 2 \\
\hline $\mathrm{SP}$ & 9 & 2,6 & 5 & 0 & 8 & 2,4 & 2 & 0 \\
\hline TO & 7 & 2,9 & 1 & 0 & 12 & 1,5 & 3 & 0 \\
\hline
\end{tabular}

Tabela 13 - Observações de Secretários - Variáveis Principais 


\begin{tabular}{|c|c|c|c|c|c|c|}
\hline & \multicolumn{3}{|c|}{ Secretários do Planejamento } & \multicolumn{3}{|c|}{ Secretários da Fazenda } \\
\hline & Superior & Mestrado & Doutorado & Superior & Mestrado & Doutorado \\
\hline $\mathrm{AC}$ & 3 & 0 & 0 & 3 & 2 & 0 \\
\hline $\mathrm{AL}$ & 6 & 1 & 0 & 7 & 0 & 0 \\
\hline $\mathrm{AM}$ & 3 & 2 & 3 & 4 & 0 & 0 \\
\hline $\mathrm{AP}$ & 4 & 2 & 1 & 2 & 0 & 0 \\
\hline $\mathrm{BA}$ & 4 & 4 & 1 & 3 & 3 & 0 \\
\hline $\mathrm{CE}$ & 4 & 5 & 0 & 2 & 1 & 1 \\
\hline $\mathrm{DF}$ & 4 & 1 & 0 & 4 & 1 & 0 \\
\hline ES & 6 & 5 & 2 & 4 & 3 & 3 \\
\hline GO & 6 & 1 & 0 & 10 & 0 & 1 \\
\hline MA & 8 & 1 & 0 & 4 & 0 & 0 \\
\hline MG & 5 & 1 & 1 & 3 & 0 & 3 \\
\hline MS & 10 & 0 & 0 & 8 & 0 & 0 \\
\hline $\mathrm{MT}$ & 6 & 0 & 1 & 6 & 2 & 0 \\
\hline $\mathrm{PA}$ & 2 & 2 & 0 & 2 & 1 & 3 \\
\hline $\mathrm{PB}$ & 6 & 1 & 1 & 7 & 0 & 0 \\
\hline $\mathrm{PE}$ & 6 & 1 & 2 & 3 & 3 & 1 \\
\hline PI & 5 & 2 & 0 & 1 & 3 & 0 \\
\hline $\mathrm{PR}$ & 9 & 1 & 1 & 6 & 0 & 0 \\
\hline $\mathrm{RJ}$ & 5 & 3 & 0 & 7 & 2 & 2 \\
\hline $\mathrm{RN}$ & 5 & 1 & 0 & 4 & 0 & 0 \\
\hline $\mathrm{RO}$ & 5 & 0 & 0 & 6 & 0 & 1 \\
\hline $\mathrm{RR}$ & 5 & 2 & 0 & 7 & 1 & 1 \\
\hline $\mathrm{RS}$ & 5 & 3 & 1 & 5 & 1 & 1 \\
\hline $\mathrm{SC}$ & 11 & 1 & 1 & 13 & 0 & 2 \\
\hline $\mathrm{SE}$ & 7 & 1 & 1 & 4 & 2 & 1 \\
\hline $\mathrm{SP}$ & 1 & 2 & 4 & 1 & 2 & 5 \\
\hline TO & 4 & 1 & 1 & 9 & 1 & 1 \\
\hline
\end{tabular}

Tabela 14 - Observações de Secretários - Nível de Instrução 


\begin{tabular}{cccccc}
\hline \multicolumn{5}{c}{ Secretários do Planejamento - Cursos Superiores } \\
\hline & Economia & Finanças & Direito & Engenharia & Outros \\
\hline AC & 1 & 0 & 0 & 1 & 1 \\
AL & 1 & 1 & 3 & 2 & 0 \\
AM & 3 & 2 & 2 & 0 & 1 \\
AP & 3 & 1 & 2 & 0 & 1 \\
BA & 5 & 1 & 1 & 1 & 0 \\
CE & 4 & 0 & 0 & 4 & 0 \\
DF & 3 & 1 & 0 & 0 & 1 \\
ES & 5 & 2 & 2 & 3 & 1 \\
GO & 2 & 0 & 3 & 1 & 1 \\
MA & 4 & 1 & 1 & 2 & 1 \\
MG & 2 & 1 & 1 & 1 & 2 \\
MS & 1 & 1 & 2 & 5 & 1 \\
MT & 1 & 1 & 2 & 3 & 0 \\
PA & 2 & 0 & 2 & 0 & 0 \\
PB & 1 & 3 & 0 & 3 & 1 \\
PE & 1 & 2 & 2 & 2 & 2 \\
PI & 5 & 0 & 2 & 0 & 0 \\
PR & 4 & 1 & 3 & 3 & 0 \\
RJ & 3 & 1 & 0 & 2 & 2 \\
RN & 1 & 1 & 0 & 4 & 0 \\
RO & 1 & 1 & 1 & 2 & 0 \\
RR & 5 & 0 & 0 & 1 & 1 \\
RS & 4 & 1 & 1 & 1 & 2 \\
SC & 1 & 3 & 3 & 3 & 3 \\
SE & 4 & 1 & 2 & 1 & 1 \\
SP & 5 & 1 & 0 & 1 & 0 \\
TO & 4 & 0 & 0 & 0 & 1 \\
\hline
\end{tabular}

Tabela 15 - Observações de Secretários do Planejamento - Curso Superior 
Secretários da Fazenda

\begin{tabular}{lccccc}
\hline & Economia & Finanças & Direito & Engenharia & Outros \\
\hline AC & 3 & 0 & 0 & 1 & 0 \\
AL & 0 & 0 & 4 & 2 & 1 \\
AM & 1 & 2 & 0 & 1 & 0 \\
AP & 0 & 1 & 0 & 1 & 0 \\
BA & 5 & 1 & 0 & 0 & 0 \\
CE & 1 & 2 & 0 & 1 & 0 \\
DF & 3 & 1 & 0 & 0 & 1 \\
ES & 5 & 0 & 2 & 2 & 1 \\
GO & 4 & 2 & 2 & 3 & 0 \\
MA & 2 & 1 & 0 & 1 & 0 \\
MG & 4 & 1 & 0 & 1 & 0 \\
MS & 1 & 1 & 3 & 0 & 3 \\
MT & 2 & 1 & 4 & 1 & 0 \\
PA & 2 & 0 & 2 & 2 & 0 \\
PB & 3 & 1 & 0 & 2 & 1 \\
PE & 6 & 0 & 1 & 0 & 0 \\
PI & 0 & 1 & 1 & 0 & 2 \\
PR & 1 & 1 & 2 & 1 & 1 \\
RJ & 5 & 2 & 0 & 3 & 1 \\
RN & 0 & 2 & 2 & 0 & 0 \\
RO & 0 & 3 & 3 & 0 & 0 \\
RR & 2 & 3 & 3 & 0 & 1 \\
RS & 5 & 2 & 0 & 0 & 0 \\
SC & 1 & 3 & 9 & 1 & 1 \\
SE & 1 & 1 & 2 & 3 & 0 \\
SP & 5 & 1 & 0 & 2 & 0 \\
TO & 4 & 1 & 3 & 0 & 0 \\
\hline & 1 & & 0 & \\
\hline
\end{tabular}

Tabela 16 - Observações de Secretários da Fazenda - Curso Superior 


\section{APÊNDICE B - Matrizes de Correlação}

Neste apêndice apresenta-se a matrizes de correlação das características dos Secretários da Fazenda (incluindo o Resultado Fiscal dos estados) na Tabela 17 e a matriz de características dos Secretários do Planejamento (incluindo o Erro de Previsão) na Tabela 18. 


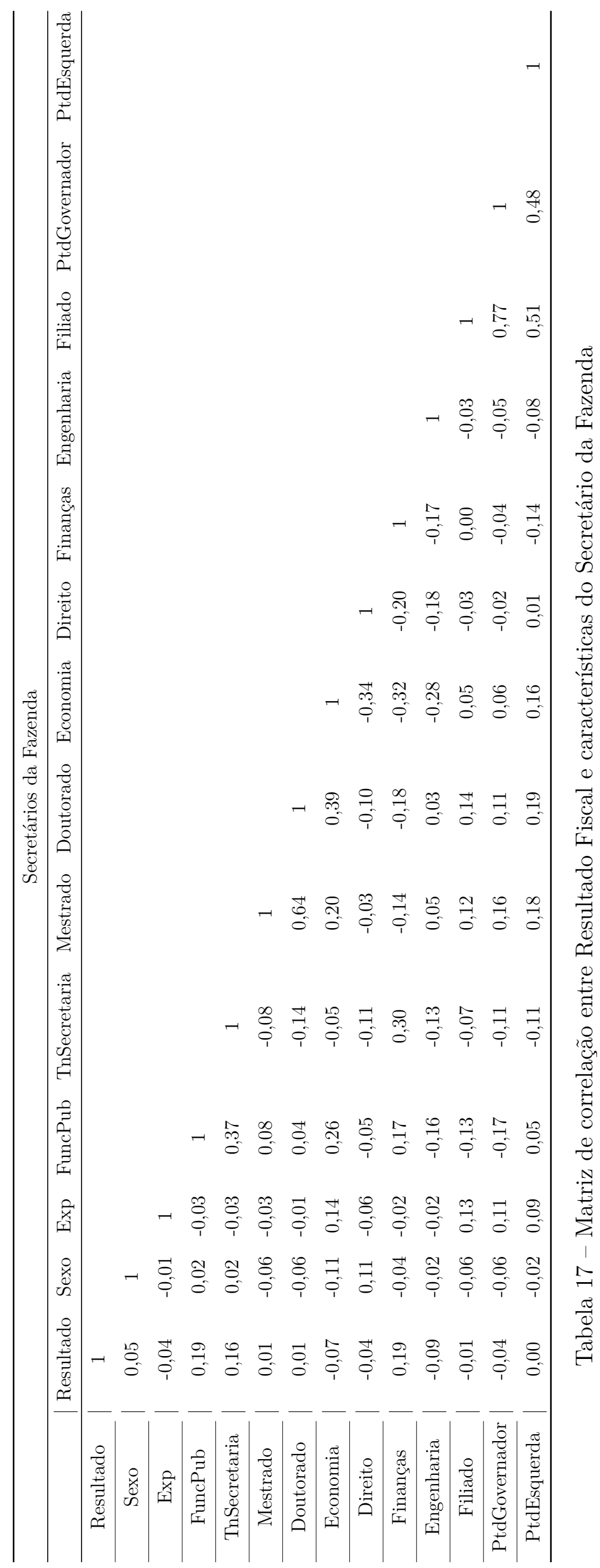




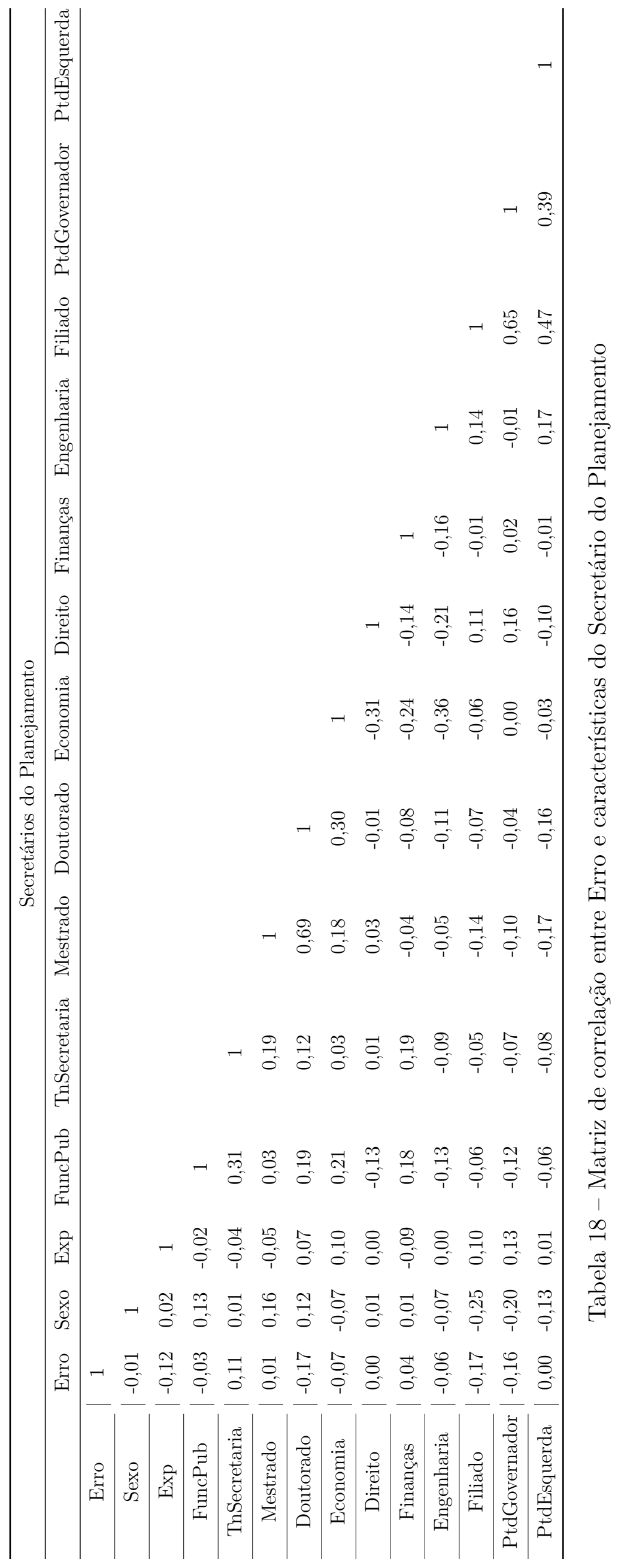




\section{APÊNDICE C - Testes e Estimações Alternativas}

Este Apêndice apresenta o teste referente à contratação de Secretários da Fazenda e demais estimações alternativas, utilizadas como teste de robustez.

Na Tabela 19 abaixo encontram-se os testes t referentes à contratação de Secretários da Fazenda após períodos de recessão econômica. Constrói-se a variável binária Sfaz_novo, que assume valor 1 quando contrata-se um novo secretário da Fazenda. Com o objetivo de analisar se períodos de recessão econômica provocam mudanças nos Secretário da Fazenda, divide-se a amostra nos grupos 1 (estados em recessão no período t-1) e o grupo 0 (demais observações). Não se descarta a hipótese nula, de que não há diferença sistemática entre a variável Sfaz_novo nos dois grupos.

\begin{tabular}{|c|}
\hline Teste t - Variável binária Sfaz_novo \\
\hline Grupo $1=$ Estado em recessão no período t-1 \\
Grupo $0=$ Demais observações \\
Graus de liberdade $=561$ \\
\hline Hipótese nula: média $(0)-$ média $(1)=0$ \\
Estatística $\mathrm{t}=-0.5588$ \\
\hline Hipótese alternativa: média $(0)$ - média $(1)$ diferente de 0 \\
$\operatorname{Pr}(\mathrm{T}>\mathrm{t})=0.5765$ \\
\hline
\end{tabular}

Tabela 19 - Teste t sobre a contratação de Secretários da Fazenda após períodos de recessão econômica. 
A Tabela 20 abaixo apresenta a estimação alternativa do efeito do Erro no Resultado Fiscal, incluindo variável binária de ideologia do governador.

\begin{tabular}{|c|c|c|c|c|c|c|}
\hline Variável Explicada = Resultado & (1) & $(2)$ & (3) & $(4)$ & $(5)$ & $(6)$ \\
\hline Erro & $\begin{array}{l}-0.0634 \\
(0.0757)\end{array}$ & $\begin{array}{l}-0.0770 \\
(0.0824)\end{array}$ & $\begin{array}{c}-0.0805^{* * *} \\
(0.0156)\end{array}$ & $\begin{array}{c}-0.105^{* * *} \\
(0.0168)\end{array}$ & $\begin{array}{c}-0.240^{* * *} \\
(0.0720)\end{array}$ & $\begin{array}{c}-0.287^{* *} \\
(0.129)\end{array}$ \\
\hline Resultado (defasado) & $\begin{array}{c}0.577^{* *} \\
(0.244)\end{array}$ & $\begin{array}{c}0.529^{* *} \\
(0.245)\end{array}$ & $\begin{array}{c}0.582^{* * *} \\
(0.0370)\end{array}$ & $\begin{array}{c}0.508^{* * *} \\
(0.0393)\end{array}$ & & \\
\hline Crescimento & $\begin{array}{l}-1.017 \\
(1.637)\end{array}$ & $\begin{array}{l}-0.898 \\
(1.787)\end{array}$ & $\begin{array}{l}-1.309 \\
(0.936)\end{array}$ & $\begin{array}{c}-1.554^{*} \\
(0.940)\end{array}$ & $\begin{array}{l}-18.70 \\
(12.98)\end{array}$ & $\begin{array}{l}-10.31 \\
(14.09)\end{array}$ \\
\hline Alesina & & $\begin{array}{l}-1.076 \\
(4.303)\end{array}$ & & $\begin{array}{l}-2.683 \\
(2.720)\end{array}$ & & $\begin{array}{c}59.19 \\
(73.63)\end{array}$ \\
\hline GovEsquerda & & $\begin{array}{l}-14.55 \\
(25.99)\end{array}$ & & $\begin{array}{c}-34.54^{* *} \\
(15.01)\end{array}$ & & $\begin{array}{l}-504.2 \\
(559.6)\end{array}$ \\
\hline Transferências & & $\begin{array}{l}-126.3 \\
(124.3)\end{array}$ & & $\begin{array}{l}-43.52 \\
(65.57)\end{array}$ & & $\begin{array}{c}651.2 \\
(825.5)\end{array}$ \\
\hline GovExperiência & & $\begin{array}{l}-3.345 \\
(3.397)\end{array}$ & & $\begin{array}{c}-4.086^{* *} \\
(2.056)\end{array}$ & & $\begin{array}{l}16.93 \\
(34.66)\end{array}$ \\
\hline Coligação & & $\begin{array}{l}-6.572 \\
(4.137)\end{array}$ & & $\begin{array}{c}-4.751^{* * *} \\
(1.564)\end{array}$ & & $\begin{array}{c}7.854 \\
(30.75)\end{array}$ \\
\hline Preeleitoral & & $\begin{array}{c}114.0 \\
(91.82)\end{array}$ & & $\begin{array}{c}-152.6^{* * *} \\
(37.55)\end{array}$ & & \\
\hline Eleitoral & & $\begin{array}{c}-31.79^{* * *} \\
(9.774)\end{array}$ & & $\begin{array}{l}-17.54 \\
(37.76)\end{array}$ & & $\begin{array}{c}174.2 \\
(490.5)\end{array}$ \\
\hline Poseleitoral & & $\begin{array}{c}246.4^{* * *} \\
(29.89)\end{array}$ & & $\begin{array}{l}-18.00 \\
(38.76)\end{array}$ & & \\
\hline Concordância & & $\begin{array}{c}14.59 \\
(10.85)\end{array}$ & & $\begin{array}{c}11.02 \\
(10.41)\end{array}$ & & $\begin{array}{c}83.23 \\
(189.6)\end{array}$ \\
\hline Concorrência & & $\begin{array}{c}4.162 \\
(5.860)\end{array}$ & & $\begin{array}{c}2.035 \\
(2.187)\end{array}$ & & $\begin{array}{c}123.8 \\
(113.8)\end{array}$ \\
\hline FracLegis & & $\begin{array}{l}-337.1 \\
(353.4)\end{array}$ & & $\begin{array}{l}-184.0 \\
(202.3)\end{array}$ & & $\begin{array}{l}-5,307 \\
(7,985)\end{array}$ \\
\hline Constante & $\begin{array}{c}222.2^{* * *} \\
(25.06)\end{array}$ & $\begin{array}{l}535.9^{*} \\
(319.2)\end{array}$ & $\begin{array}{c}196.1^{* * *} \\
(36.55)\end{array}$ & $\begin{array}{c}735.6^{* * *} \\
(267.4)\end{array}$ & $\begin{array}{l}391.3^{*} \\
(214.9)\end{array}$ & $\begin{array}{l}-136.0 \\
(6,314)\end{array}$ \\
\hline Estimador & OLS & OLS & GLS & GLS & GMM & GMM \\
\hline Controles Políticos & Não & Sim & Não & Sim & Não & Sim \\
\hline Observações & 602 & 562 & 602 & 562 & 609 & 569 \\
\hline
\end{tabular}

Tabela 20 - Regressão do Resultado Fiscal explicado pelo Erro de Previsão, incluindo variável binária de ideologia do governador 
A Tabela 21 apresenta a estimação alternativa do efeito do Secretário da Fazenda no Resultado Fiscal, excluindo gênero do secretário.

\begin{tabular}{|c|c|c|c|c|c|c|}
\hline Variável Explicada = Resultado & (1) & (2) & (3) & (4) & (5) & $(6)$ \\
\hline Erro & $\begin{array}{c}-0.0729 \\
(0.0646)\end{array}$ & $\begin{array}{l}-0.0856 \\
(0.0675)\end{array}$ & $\begin{array}{c}-0.0876^{* * *} \\
(0.0161)\end{array}$ & $\begin{array}{c}-0.109^{* * *} \\
(0.0178)\end{array}$ & $\begin{array}{c}-0.498^{* * *} \\
(0.0893)\end{array}$ & $\begin{array}{c}-0.977^{* * *} \\
(0.271)\end{array}$ \\
\hline Resultado (defasado) & $\begin{array}{c}0.523^{* *} \\
(0.216)\end{array}$ & $\begin{array}{c}0.469^{* *} \\
(0.206)\end{array}$ & $\begin{array}{c}0.559^{* * *} \\
(0.0379)\end{array}$ & $\begin{array}{c}0.492^{* * *} \\
(0.0401)\end{array}$ & & \\
\hline Crescimento & $\begin{array}{l}-1.462 \\
(1.379)\end{array}$ & $\begin{array}{l}-1.324 \\
(1.667)\end{array}$ & $\begin{array}{l}-1.524 \\
(0.942)\end{array}$ & $\begin{array}{c}-1.851^{*} \\
(0.956)\end{array}$ & $\begin{array}{c}-24.54^{* * *} \\
(8.345)\end{array}$ & $\begin{array}{c}-33.83^{*} \\
(17.78)\end{array}$ \\
\hline Sfaz_Exp & $\begin{array}{l}-5.314 \\
(3.376)\end{array}$ & $\begin{array}{l}-6.068^{*} \\
(3.115)\end{array}$ & $\begin{array}{c}-7.479^{* *} \\
(3.351)\end{array}$ & $\begin{array}{c}-8.131^{* *} \\
(3.427)\end{array}$ & $\begin{array}{c}29.93 \\
(40.38)\end{array}$ & $\begin{array}{l}-11.09 \\
(72.95)\end{array}$ \\
\hline Sfaz_FuncPub & $\begin{array}{c}1.200 \\
(19.90)\end{array}$ & $\begin{array}{l}-10.04 \\
(22.73)\end{array}$ & $\begin{array}{c}4.683 \\
(15.79)\end{array}$ & $\begin{array}{c}2.445 \\
(17.06)\end{array}$ & $\begin{array}{c}2.738 \\
(153.8)\end{array}$ & $\begin{array}{l}-490.1 \\
(355.6)\end{array}$ \\
\hline Sfaz_TnSecretaria & $\begin{array}{l}-1.536 \\
(60.73)\end{array}$ & $\begin{array}{c}20.24 \\
(66.81)\end{array}$ & $\begin{array}{l}-33.26 \\
(23.09)\end{array}$ & $\begin{array}{l}-19.27 \\
(24.63)\end{array}$ & $\begin{array}{l}-348.3^{*} \\
(211.0)\end{array}$ & $\begin{array}{c}376.9 \\
(418.0)\end{array}$ \\
\hline Sfaz_Mestrado & $\begin{array}{l}-12.27 \\
(33.91)\end{array}$ & $\begin{array}{l}-19.42 \\
(35.07)\end{array}$ & $\begin{array}{c}0.476 \\
(24.36)\end{array}$ & $\begin{array}{l}-3.354 \\
(27.08)\end{array}$ & $\begin{array}{l}-456.9 \\
(280.0)\end{array}$ & $\begin{array}{l}-291.6 \\
(563.6)\end{array}$ \\
\hline Sfaz_Doutorado & $\begin{array}{c}32.63 \\
(23.27)\end{array}$ & $\begin{array}{c}38.43 \\
(26.38)\end{array}$ & $\begin{array}{c}9.969 \\
(21.79)\end{array}$ & $\begin{array}{l}15.43 \\
(25.00)\end{array}$ & $\begin{array}{l}-110.3 \\
(197.8)\end{array}$ & $\begin{array}{l}-241.9 \\
(389.8)\end{array}$ \\
\hline Sfaz_Economia & $\begin{array}{l}-29.75 \\
(29.63)\end{array}$ & $\begin{array}{l}-9.781 \\
(31.37)\end{array}$ & $\begin{array}{l}-39.31^{*} \\
(21.74)\end{array}$ & $\begin{array}{l}-27.22 \\
(23.83)\end{array}$ & $\begin{array}{l}-5.859 \\
(219.8)\end{array}$ & $\begin{array}{c}619.0 \\
(423.5)\end{array}$ \\
\hline Sfaz_Direito & $\begin{array}{l}-7.907 \\
(26.64)\end{array}$ & $\begin{array}{l}-8.334 \\
(32.52)\end{array}$ & $\begin{array}{l}-16.22 \\
(20.43)\end{array}$ & $\begin{array}{l}-25.28 \\
(22.88)\end{array}$ & $\begin{array}{c}190.5 \\
(165.3)\end{array}$ & $\begin{array}{c}976.9^{* *} \\
(412.6)\end{array}$ \\
\hline Sfaz_Finanças & $\begin{array}{c}26.66 \\
(54.02)\end{array}$ & $\begin{array}{c}51.07 \\
(54.94)\end{array}$ & $\begin{array}{c}4.777 \\
(22.61)\end{array}$ & $\begin{array}{c}15.61 \\
(23.58)\end{array}$ & $\begin{array}{c}3.208 \\
(158.4)\end{array}$ & $\begin{array}{c}496.6 \\
(308.9)\end{array}$ \\
\hline Sfaz_Engenharia & $\begin{array}{l}-51.90^{*} \\
(28.60)\end{array}$ & $\begin{array}{l}-36.86 \\
(29.19)\end{array}$ & $\begin{array}{l}-25.27 \\
(22.64)\end{array}$ & $\begin{array}{l}-24.41 \\
(24.94)\end{array}$ & $\begin{array}{c}-473.8^{* *} \\
(229.1)\end{array}$ & $\begin{array}{l}500.8 \\
(621.3)\end{array}$ \\
\hline Sfaz_Filiado & $\begin{array}{c}32.20 \\
(28.65)\end{array}$ & $\begin{array}{c}26.87 \\
(31.39)\end{array}$ & $\begin{array}{l}32.64^{*} \\
(19.12)\end{array}$ & $\begin{array}{c}17.63 \\
(21.85)\end{array}$ & $\begin{array}{c}37.11 \\
(198.1)\end{array}$ & $\begin{array}{l}-65.55 \\
(419.9)\end{array}$ \\
\hline Sfaz_PtdGovernador & $\begin{array}{l}-15.95 \\
(25.17)\end{array}$ & $\begin{array}{l}-15.16 \\
(24.11)\end{array}$ & $\begin{array}{l}-13.69 \\
(20.19)\end{array}$ & $\begin{array}{c}-17.00 \\
(22.13)\end{array}$ & $\begin{array}{l}-16.78 \\
(234.8)\end{array}$ & $\begin{array}{l}-65.87 \\
(563.3)\end{array}$ \\
\hline Constante & $\begin{array}{c}215.4^{* * *} \\
(48.70)\end{array}$ & $\begin{array}{c}782.0^{* *} \\
(322.2)\end{array}$ & $\begin{array}{c}221.9^{* * *} \\
(42.77)\end{array}$ & $\begin{array}{c}977.5^{* * *} \\
(313.2)\end{array}$ & $\begin{array}{c}693.1^{* * *} \\
(211.2)\end{array}$ & $\begin{array}{c}7,199 \\
(5,622)\end{array}$ \\
\hline Estimador & OLS & OLS & GLS & GLS & GMM & GMM \\
\hline Controles Político-Institucionais & Não & Sim & Não & Sim & Não & Sim \\
\hline Observações & 588 & 548 & 588 & 548 & 595 & 555 \\
\hline
\end{tabular}

Tabela 21 - Regressão das características dos Secretários da Fazenda, exclusive gênero, sobre o Resultado Fiscal 
A Tabela 22 contém a estimação alternativa do efeito do Secretário da Fazenda no Resultado Fiscal, excluindo Erro de Previsão das variáveis explicativas.

\begin{tabular}{|c|c|c|c|c|c|c|}
\hline Variável Explicada = Resultado & (1) & $(2)$ & (3) & (4) & (5) & (6) \\
\hline Resultado (defasado) & $\begin{array}{c}0.523^{* *} \\
(0.247)\end{array}$ & $\begin{array}{c}0.468^{* *} \\
(0.201)\end{array}$ & $\begin{array}{c}0.591^{* * *} \\
(0.0385)\end{array}$ & $\begin{array}{c}0.532^{* * *} \\
(0.0409)\end{array}$ & & \\
\hline Crescimento & $\begin{array}{l}-0.949 \\
(1.330)\end{array}$ & $\begin{array}{c}-0.722 \\
(1.498)\end{array}$ & $\begin{array}{l}-0.889 \\
(0.958)\end{array}$ & $\begin{array}{l}-1.013 \\
(0.979)\end{array}$ & $\begin{array}{l}-14.41 \\
(8.866)\end{array}$ & $\begin{array}{l}-30.07 \\
(19.55)\end{array}$ \\
\hline Sfaz_Sexo & $\begin{array}{l}-10.06 \\
(48.27)\end{array}$ & $\begin{array}{l}-14.69 \\
(46.17)\end{array}$ & $\begin{array}{l}-2.968 \\
(29.26)\end{array}$ & $\begin{array}{l}-12.27 \\
(31.86)\end{array}$ & $\begin{array}{c}481.6 \\
(341.5)\end{array}$ & $\begin{array}{r}1,086 \\
(857.6)\end{array}$ \\
\hline Sfaz_Exp & $\begin{array}{l}-4.298 \\
(3.500)\end{array}$ & $\begin{array}{l}-5.543 \\
(3.444)\end{array}$ & $\begin{array}{c}-5.959^{*} \\
(3.335)\end{array}$ & $\begin{array}{c}-7.307^{* *} \\
(3.510)\end{array}$ & $\begin{array}{c}66.17 \\
(49.10)\end{array}$ & $\begin{array}{r}96.69 \\
(96.12)\end{array}$ \\
\hline Sfaz_FuncPub & $\begin{array}{c}4.032 \\
(17.98)\end{array}$ & $\begin{array}{l}-6.344 \\
(21.74)\end{array}$ & $\begin{array}{c}1.395 \\
(16.02)\end{array}$ & $\begin{array}{c}0.909 \\
(17.36)\end{array}$ & $\begin{array}{c}118.1 \\
(164.6)\end{array}$ & $\begin{array}{r}18.60 \\
(343.3)\end{array}$ \\
\hline Sfaz_TnSecretaria & $\begin{array}{l}-8.879 \\
(60.49)\end{array}$ & $\begin{array}{c}14.19 \\
(72.85)\end{array}$ & $\begin{array}{l}-32.95 \\
(23.68)\end{array}$ & $\begin{array}{l}-15.09 \\
(24.97)\end{array}$ & $\begin{array}{c}102.3 \\
(213.2)\end{array}$ & $\begin{array}{l}-131.5 \\
(436.4)\end{array}$ \\
\hline Sfaz_Mestrado & $\begin{array}{l}-10.61 \\
(34.17)\end{array}$ & $\begin{array}{l}-17.17 \\
(36.01)\end{array}$ & $\begin{array}{l}2.760 \\
(25.03)\end{array}$ & $\begin{array}{c}2.544 \\
(27.40)\end{array}$ & $\begin{array}{l}-18.37 \\
(301.2)\end{array}$ & $\begin{array}{r}80.29 \\
(665.0)\end{array}$ \\
\hline Sfaz_Doutorado & $\begin{array}{c}35.03 \\
(23.24)\end{array}$ & $\begin{array}{l}42.16 \\
(26.25)\end{array}$ & $\begin{array}{l}15.98 \\
(22.42)\end{array}$ & $\begin{array}{c}22.73 \\
(25.43)\end{array}$ & $\begin{array}{c}67.09 \\
(208.5)\end{array}$ & $\begin{array}{l}-25.61 \\
(408.9)\end{array}$ \\
\hline Sfaz_Economia & $\begin{array}{l}-27.22 \\
(26.62)\end{array}$ & $\begin{array}{l}-9.670 \\
(30.09)\end{array}$ & $\begin{array}{l}-25.67 \\
(22.12)\end{array}$ & $\begin{array}{l}-17.87 \\
(24.49)\end{array}$ & $\begin{array}{l}-243.3 \\
(231.3)\end{array}$ & $\begin{array}{r}702.2 \\
(458.3)\end{array}$ \\
\hline Sfaz_Direito & $\begin{array}{l}-3.673 \\
(25.07)\end{array}$ & $\begin{array}{l}-3.769 \\
(30.18)\end{array}$ & $\begin{array}{l}-5.709 \\
(20.70)\end{array}$ & $\begin{array}{l}-13.36 \\
(23.35)\end{array}$ & $\begin{array}{c}44.22 \\
(179.6)\end{array}$ & $\begin{array}{r}671.2 \\
(438.1)\end{array}$ \\
\hline Sfaz_Finanças & $\begin{array}{c}30.13 \\
(54.33)\end{array}$ & $\begin{array}{c}53.24 \\
(53.38)\end{array}$ & $\begin{array}{l}19.47 \\
(22.96)\end{array}$ & $\begin{array}{c}32.62 \\
(23.96)\end{array}$ & $\begin{array}{c}204.4 \\
(172.5)\end{array}$ & $\begin{array}{r}541.9 \\
(387.7)\end{array}$ \\
\hline Sfaz_Engenharia & $\begin{array}{c}-56.22^{* *} \\
(25.62)\end{array}$ & $\begin{array}{l}-44.68 \\
(28.26)\end{array}$ & $\begin{array}{l}-28.46 \\
(22.99)\end{array}$ & $\begin{array}{l}-29.51 \\
(25.39)\end{array}$ & $\begin{array}{c}-812.4^{* * *} \\
(244.3)\end{array}$ & $\begin{array}{l}-433.6 \\
(591.2)\end{array}$ \\
\hline Sfaz_Filiado & $\begin{array}{c}24.73 \\
(28.40)\end{array}$ & $\begin{array}{l}21.83 \\
(31.13)\end{array}$ & $\begin{array}{c}25.67 \\
(19.19)\end{array}$ & $\begin{array}{l}17.48 \\
(22.28)\end{array}$ & $\begin{array}{c}213.7 \\
(214.2)\end{array}$ & $\begin{array}{l}-334.5 \\
(439.8)\end{array}$ \\
\hline Sfaz_PtdGovernador & $\begin{array}{l}-13.40 \\
(25.14)\end{array}$ & $\begin{array}{l}-13.90 \\
(25.29)\end{array}$ & $\begin{array}{l}-13.83 \\
(20.38)\end{array}$ & $\begin{array}{l}-20.02 \\
(22.51)\end{array}$ & $\begin{array}{l}-357.7 \\
(249.7)\end{array}$ & $\begin{array}{r}279.1 \\
(588.5)\end{array}$ \\
\hline Constante & $\begin{array}{c}201.4^{* * *} \\
(49.02)\end{array}$ & $\begin{array}{c}843.4^{* *} \\
(353.8)\end{array}$ & $\begin{array}{c}201.7^{* * * *} \\
(43.19)\end{array}$ & $\begin{array}{c}666.4^{* *} \\
(314.6)\end{array}$ & $\begin{array}{c}599.0^{* * *} \\
(226.4)\end{array}$ & $\begin{array}{c}2,561 \\
(6,447)\end{array}$ \\
\hline Estimador & OLS & OLS & GLS & GLS & GMM & GMM \\
\hline Controles Político-Institucionais & Não & Sim & Não & Sim & Não & Sim \\
\hline Observações & 588 & 548 & 588 & 548 & 595 & 555 \\
\hline
\end{tabular}

Nota: ${ }^{* * *}$ indica significância estatística ao nível de $1 \%,{ }^{* *}$ de $5 \%$ e ${ }^{*}$ ao nível de $10 \%$.

Tabela 22 - Regressão das características dos Secretários da Fazenda sobre o Resultado Fiscal, excluindo o Erro de Previsão das variáveis explicativas 
A Tabela 23 apresenta estimação alternativa do efeito do Secretário da Fazenda no Resultado Fiscal, incluindo variáveis binárias de ideologia do governador e do secretário da Fazenda.

\begin{tabular}{|c|c|c|c|c|c|c|}
\hline Variável Explicada = Resultado & (1) & $(2)$ & (3) & (4) & $(5)$ & $(6)$ \\
\hline Erro & $\begin{array}{l}-0.0720 \\
(0.0615)\end{array}$ & $\begin{array}{l}-0.0840 \\
(0.0636)\end{array}$ & $\begin{array}{c}-0.0900 * * * \\
(0.0160)\end{array}$ & $\begin{array}{c}-0.108^{* * *} \\
(0.0175)\end{array}$ & $\begin{array}{c}-0.498^{* * *} \\
(0.0894)\end{array}$ & $\begin{array}{l}-0.262 \\
(1.044)\end{array}$ \\
\hline Resultado (defasado) & $\begin{array}{c}0.516^{* *} \\
(0.214)\end{array}$ & $\begin{array}{c}0.462^{* *} \\
(0.200)\end{array}$ & $\begin{array}{c}0.543^{* * *} \\
(0.0380)\end{array}$ & $\begin{array}{c}0.482^{* * *} \\
(0.0404)\end{array}$ & & \\
\hline Crescimento & $\begin{array}{l}-1.583 \\
(1.449)\end{array}$ & $\begin{array}{l}-1.340 \\
(1.739)\end{array}$ & $\begin{array}{c}-1.658^{*} \\
(0.936)\end{array}$ & $\begin{array}{c}-1.905^{* *} \\
(0.954)\end{array}$ & $\begin{array}{c}-24.56^{* * *} \\
(8.350)\end{array}$ & $\begin{array}{c}68.71 \\
(227.4)\end{array}$ \\
\hline Sfaz_Exp & $\begin{array}{l}-5.507^{*} \\
(3.054)\end{array}$ & $\begin{array}{c}-6.032^{*} \\
(3.230)\end{array}$ & $\begin{array}{c}-7.971^{* *} \\
(3.287)\end{array}$ & $\begin{array}{c}-8.330^{* *} \\
(3.402)\end{array}$ & $\begin{array}{c}31.11 \\
(40.48)\end{array}$ & $\begin{array}{l}-80.79 \\
(692.1)\end{array}$ \\
\hline Sfaz_FuncPub & $\begin{array}{c}3.484 \\
(19.83)\end{array}$ & $\begin{array}{l}-7.126 \\
(23.14)\end{array}$ & $\begin{array}{c}9.366 \\
(15.79)\end{array}$ & $\begin{array}{c}6.051 \\
(17.16)\end{array}$ & $\begin{array}{c}37.30 \\
(169.1)\end{array}$ & $\begin{array}{c}831.6 \\
(4,459)\end{array}$ \\
\hline Sfaz_TnSecretaria & $\begin{array}{l}-10.93 \\
(58.42)\end{array}$ & $\begin{array}{l}16.87 \\
(65.43)\end{array}$ & $\begin{array}{l}-44.40^{*} \\
(23.38)\end{array}$ & $\begin{array}{l}-23.30 \\
(24.96)\end{array}$ & $\begin{array}{c}-361.3^{*} \\
(212.8)\end{array}$ & $\begin{array}{c}3,165 \\
(8,923)\end{array}$ \\
\hline Sfaz_Mestrado & $\begin{array}{l}-18.64 \\
(33.45)\end{array}$ & $\begin{array}{l}-19.47 \\
(33.95)\end{array}$ & $\begin{array}{l}-9.165 \\
(24.42)\end{array}$ & $\begin{array}{l}-7.784 \\
(27.35)\end{array}$ & $\begin{array}{l}-468.6^{*} \\
(281.2)\end{array}$ & $\begin{array}{l}-143.4 \\
(5,018)\end{array}$ \\
\hline Sfaz_Doutorado & $\begin{array}{c}36.50 \\
(23.76)\end{array}$ & $\begin{array}{l}40.96 \\
(28.14)\end{array}$ & $\begin{array}{c}15.37 \\
(21.89)\end{array}$ & $\begin{array}{c}16.63 \\
(25.05)\end{array}$ & $\begin{array}{l}-125.9 \\
(200.4)\end{array}$ & $\begin{array}{c}932.6 \\
(5,312)\end{array}$ \\
\hline Sfaz_Economia & $\begin{array}{l}-23.52 \\
(31.43)\end{array}$ & $\begin{array}{l}-8.699 \\
(33.24)\end{array}$ & $\begin{array}{l}-31.06 \\
(21.83)\end{array}$ & $\begin{array}{l}-21.31 \\
(23.94)\end{array}$ & $\begin{array}{l}-34.29 \\
(227.4)\end{array}$ & $\begin{array}{l}-1,632 \\
(3,731)\end{array}$ \\
\hline Sfaz_Direito & $\begin{array}{l}-1.200 \\
(26.97)\end{array}$ & $\begin{array}{l}-7.346 \\
(32.76)\end{array}$ & $\begin{array}{l}-8.201 \\
(20.55)\end{array}$ & $\begin{array}{l}-15.83 \\
(23.17)\end{array}$ & $\begin{array}{c}196.5 \\
(165.8)\end{array}$ & $\begin{array}{c}1,232 \\
(4,448)\end{array}$ \\
\hline Sfaz_Finanças & $\begin{array}{l}28.28 \\
(53.89)\end{array}$ & $\begin{array}{c}50.84 \\
(55.51)\end{array}$ & $\begin{array}{l}5.310 \\
(22.34)\end{array}$ & $\begin{array}{l}14.88 \\
(23.50)\end{array}$ & $\begin{array}{l}-26.01 \\
(169.2)\end{array}$ & $\begin{array}{l}-533.7 \\
(3,026)\end{array}$ \\
\hline Sfaz_Engenharia & $\begin{array}{l}-52.54^{*} \\
(28.59)\end{array}$ & $\begin{array}{l}-38.65 \\
(28.70)\end{array}$ & $\begin{array}{l}-25.93 \\
(22.53)\end{array}$ & $\begin{array}{l}-24.01 \\
(24.86)\end{array}$ & $\begin{array}{c}-458.2^{* *} \\
(231.5)\end{array}$ & $\begin{array}{l}-1,554 \\
(3,844)\end{array}$ \\
\hline Sfaz_Filiado & $\begin{array}{c}41.57 \\
(30.44)\end{array}$ & $\begin{array}{l}27.64 \\
(32.31)\end{array}$ & $\begin{array}{l}45.03^{* *} \\
(19.60)\end{array}$ & $\begin{array}{c}21.31 \\
(22.05)\end{array}$ & $\begin{array}{c}68.42 \\
(208.2)\end{array}$ & $\begin{array}{c}1,560 \\
(4,756)\end{array}$ \\
\hline Sfaz_PtdGovernador & $\begin{array}{l}-9.558 \\
(24.01)\end{array}$ & $\begin{array}{l}-10.99 \\
(24.27)\end{array}$ & $\begin{array}{l}-6.481 \\
(20.08)\end{array}$ & $\begin{array}{l}-7.393 \\
(22.58)\end{array}$ & $\begin{array}{l}-0.812 \\
(237.1)\end{array}$ & $\begin{array}{l}-2,838 \\
(7,552)\end{array}$ \\
\hline Sfaz_Esq & $\begin{array}{c}-44.63^{* *} \\
(22.52)\end{array}$ & $\begin{array}{l}-7.285 \\
(21.61)\end{array}$ & $\begin{array}{c}-54.82^{* *} \\
(21.38)\end{array}$ & $\begin{array}{l}-21.85 \\
(26.24)\end{array}$ & $\begin{array}{l}-100.3 \\
(203.5)\end{array}$ & $\begin{array}{c}2,450 \\
(7,363)\end{array}$ \\
\hline GovEsquerda & & $\begin{array}{l}-18.71 \\
(20.98)\end{array}$ & & $\begin{array}{l}-27.11 \\
(17.71)\end{array}$ & & $\begin{array}{c}2,253 \\
(7,240)\end{array}$ \\
\hline Constante & $\begin{array}{c}56.37 \\
(50.91)\end{array}$ & $\begin{array}{c}945.8^{* * *} \\
(282.9)\end{array}$ & $\begin{array}{c}241.9^{* * *} \\
(43.05)\end{array}$ & $\begin{array}{c}859.2^{* * *} \\
(290.7)\end{array}$ & $\begin{array}{c}688.8^{* * *} \\
(211.5)\end{array}$ & $\begin{array}{l}-16,448 \\
(47,667)\end{array}$ \\
\hline Estimador & OLS & OLS & GLS & GLS & GMM & GMM \\
\hline Controles Político-Institucionais & Não & Sim & Não & Sim & Não & Sim \\
\hline Observações & 588 & 548 & 588 & 548 & 595 & 555 \\
\hline
\end{tabular}

Tabela 23 - Regressão das características dos Secretários da Fazenda sobre o Resultado Fiscal, incluindo variáveis binárias de ideologia do governador e do secretário 
A Tabela 24 contém a estimação alternativa do efeito do Secretário do Planejamento no Erro de Previsão, excluindo gênero do secretário.

\begin{tabular}{|c|c|c|c|c|}
\hline Variável Explicada = Erro & (1) & $(2)$ & $(3)$ & (4) \\
\hline Crescimento & $\begin{array}{c}-6.549^{* *} \\
(3.073)\end{array}$ & $\begin{array}{c}-7.342^{*} \\
(3.917)\end{array}$ & $\begin{array}{c}-5.344^{* * *} \\
(1.604)\end{array}$ & $\begin{array}{c}-4.822^{* * *} \\
(1.859)\end{array}$ \\
\hline ÍndiceAlesina (defasado) & $\begin{array}{c}-21.28^{* *} \\
(9.149)\end{array}$ & $\begin{array}{c}-18.15^{* *} \\
(9.203)\end{array}$ & $\begin{array}{c}-20.59^{* *} \\
(8.549)\end{array}$ & $\begin{array}{c}-18.80^{* *} \\
(8.633)\end{array}$ \\
\hline Splan_Exp & $\begin{array}{c}-19.89^{* *} \\
(9.997)\end{array}$ & $\begin{array}{l}-14.16 \\
(10.53)\end{array}$ & $\begin{array}{c}-15.21^{* *} \\
(6.740)\end{array}$ & $\begin{array}{c}-13.19^{*} \\
(6.914)\end{array}$ \\
\hline Splan_FuncPub & $\begin{array}{l}-23.31 \\
(37.59)\end{array}$ & $\begin{array}{c}13.89 \\
(43.33)\end{array}$ & $\begin{array}{l}-26.24 \\
(34.81)\end{array}$ & $\begin{array}{l}-27.52 \\
(35.67)\end{array}$ \\
\hline Splan_TnSecretaria & $\begin{array}{c}178.1 \\
(121.3)\end{array}$ & $\begin{array}{c}113.7 \\
(121.7)\end{array}$ & $\begin{array}{c}135.6^{* *} \\
(59.95)\end{array}$ & $\begin{array}{l}105.7^{*} \\
(60.60)\end{array}$ \\
\hline Splan_Mestrado & $\begin{array}{c}128.4 \\
(81.72)\end{array}$ & $\begin{array}{c}184.8^{* *} \\
(88.21)\end{array}$ & $\begin{array}{c}57.74 \\
(57.00)\end{array}$ & $\begin{array}{c}92.76 \\
(58.12)\end{array}$ \\
\hline Splan_Doutorado & $\begin{array}{l}-129.1^{*} \\
(73.43)\end{array}$ & $\begin{array}{c}-175.6^{* *} \\
(74.25)\end{array}$ & $\begin{array}{l}-55.86 \\
(50.59)\end{array}$ & $\begin{array}{l}-62.97 \\
(52.25)\end{array}$ \\
\hline Splan_Economia & $\begin{array}{l}-66.54 \\
(51.73)\end{array}$ & $\begin{array}{l}-58.71 \\
(56.21)\end{array}$ & $\begin{array}{c}-68.98^{*} \\
(40.73)\end{array}$ & $\begin{array}{c}-75.28^{*} \\
(42.26)\end{array}$ \\
\hline Splan_Direito & $\begin{array}{l}-97.68 \\
(67.39)\end{array}$ & $\begin{array}{l}-78.34 \\
(67.85)\end{array}$ & $\begin{array}{l}-91.02^{*} \\
(48.79)\end{array}$ & $\begin{array}{l}-79.87 \\
(49.90)\end{array}$ \\
\hline Splan_Finanças & $\begin{array}{l}-110.8 \\
(75.28)\end{array}$ & $\begin{array}{c}-124.6^{*} \\
(70.66)\end{array}$ & $\begin{array}{c}-161.5^{* * *} \\
(50.91)\end{array}$ & $\begin{array}{c}-173.9 * * * \\
(53.42)\end{array}$ \\
\hline Splan_Engenharia & $\begin{array}{l}-83.70^{*} \\
(48.27)\end{array}$ & $\begin{array}{l}-81.97 \\
(57.38)\end{array}$ & $\begin{array}{c}-94.92^{* *} \\
(42.70)\end{array}$ & $\begin{array}{c}-113.5^{* *} \\
(44.93)\end{array}$ \\
\hline Splan_Filiado & $\begin{array}{l}-27.17 \\
(47.38)\end{array}$ & $\begin{array}{l}-55.15 \\
(62.96)\end{array}$ & $\begin{array}{l}-13.66 \\
(34.36)\end{array}$ & $\begin{array}{l}-30.59 \\
(36.89)\end{array}$ \\
\hline Splan_PtdGovernador & $\begin{array}{l}-43.62 \\
(59.84)\end{array}$ & $\begin{array}{l}-37.27 \\
(65.25)\end{array}$ & $\begin{array}{l}-7.373 \\
(36.79)\end{array}$ & $\begin{array}{l}-8.793 \\
(39.15)\end{array}$ \\
\hline Constante & $\begin{array}{c}1,416^{* *} \\
(584.2)\end{array}$ & $\begin{array}{c}1,539 \\
(1,070)\end{array}$ & $\begin{array}{c}1,567^{* * *} \\
(583.9)\end{array}$ & $\begin{array}{c}639.4 \\
(815.4)\end{array}$ \\
\hline Estimador & OLS & OLS & GLS & GLS \\
\hline Controles Político-Institucionais & Não & Sim & Não & Sim \\
\hline Observações & 591 & 540 & 591 & 540 \\
\hline
\end{tabular}

Nota: *** indica significância estatística ao nível de $1 \%, * *$ de $5 \%$ e * ao nível de $10 \%$.

Tabela 24 - Regressão das características dos Secretários do Planejamento, exclusive gênero, sobre o Erro de Previsão 
A Tabela 25 apresenta a estimação alternativa do efeito do Secretário do Planejamento no Erro de Previsão, incluindo variáveis binárias de ideologia do secretário e do governador.

\begin{tabular}{|c|c|c|c|c|}
\hline Variável Explicada = Erro & (1) & $(2)$ & $(3)$ & $(4)$ \\
\hline Crescimento & $\begin{array}{c}-6.573^{* *} \\
(3.108)\end{array}$ & $\begin{array}{c}-6.997^{*} \\
(3.665)\end{array}$ & $\begin{array}{c}-5.366^{* * *} \\
(1.606)\end{array}$ & $\begin{array}{c}-4.562^{* *} \\
(1.869)\end{array}$ \\
\hline ÍndiceAlesina (defasado) & $\begin{array}{c}-18.41^{* *} \\
(8.589)\end{array}$ & $\begin{array}{c}-15.84^{* *} \\
(7.610)\end{array}$ & $\begin{array}{c}-17.08^{* *} \\
(7.700)\end{array}$ & $\begin{array}{c}-14.44^{*} \\
(7.907)\end{array}$ \\
\hline Splan_Exp & $\begin{array}{c}-18.36^{*} \\
(10.10)\end{array}$ & $\begin{array}{l}-11.64 \\
(9.732)\end{array}$ & $\begin{array}{c}-15.06^{* *} \\
(6.731)\end{array}$ & $\begin{array}{c}-12.51^{*} \\
(6.959)\end{array}$ \\
\hline Splan_FuncPub & $\begin{array}{l}-29.47 \\
(39.45)\end{array}$ & $\begin{array}{c}8.355 \\
(44.31)\end{array}$ & $\begin{array}{l}-26.06 \\
(34.88)\end{array}$ & $\begin{array}{l}-27.38 \\
(36.04)\end{array}$ \\
\hline Splan_TnSecretaria & $\begin{array}{c}181.3 \\
(118.4)\end{array}$ & $\begin{array}{c}119.6 \\
(118.3)\end{array}$ & $\begin{array}{c}140.0^{* *} \\
(59.72)\end{array}$ & $\begin{array}{l}117.1^{*} \\
(60.74)\end{array}$ \\
\hline Splan_Mestrado & $\begin{array}{l}139.0^{*} \\
(82.66)\end{array}$ & $\begin{array}{c}200.1^{* *} \\
(92.14)\end{array}$ & $\begin{array}{c}71.51 \\
(56.92)\end{array}$ & $\begin{array}{l}104.7^{*} \\
(58.45)\end{array}$ \\
\hline Splan_Doutorado & $\begin{array}{c}-132.1^{*} \\
(72.38)\end{array}$ & $\begin{array}{c}-178.8^{* *} \\
(73.86)\end{array}$ & $\begin{array}{l}-67.81 \\
(50.12)\end{array}$ & $\begin{array}{l}-71.49 \\
(51.94)\end{array}$ \\
\hline Splan_Economia & $\begin{array}{c}-75.50 \\
(50.20)\end{array}$ & $\begin{array}{l}-68.78 \\
(53.53)\end{array}$ & $\begin{array}{c}-69.18^{*} \\
(40.52)\end{array}$ & $\begin{array}{c}-78.90^{*} \\
(42.13)\end{array}$ \\
\hline Splan_Direito & $\begin{array}{l}-92.43 \\
(67.09)\end{array}$ & $\begin{array}{l}-68.24 \\
(67.05)\end{array}$ & $\begin{array}{c}-82.59^{*} \\
(49.23)\end{array}$ & $\begin{array}{l}-73.28 \\
(50.57)\end{array}$ \\
\hline Splan_Finanças & $\begin{array}{l}-107.3 \\
(75.19)\end{array}$ & $\begin{array}{c}-124.4^{*} \\
(69.80)\end{array}$ & $\begin{array}{c}-159.5^{* * *} \\
(50.57)\end{array}$ & $\begin{array}{c}-172.9^{* * * *} \\
(53.81)\end{array}$ \\
\hline Splan_Engenharia & $\begin{array}{c}-91.35^{*} \\
(50.39)\end{array}$ & $\begin{array}{l}-94.11^{*} \\
(57.01)\end{array}$ & $\begin{array}{c}-98.59^{* *} \\
(42.88)\end{array}$ & $\begin{array}{c}-117.8^{* * *} \\
(45.64)\end{array}$ \\
\hline Splan_Filiado & $\begin{array}{l}-49.98 \\
(51.59)\end{array}$ & $\begin{array}{l}-84.77 \\
(64.48)\end{array}$ & $\begin{array}{l}-27.63 \\
(37.43)\end{array}$ & $\begin{array}{l}-44.55 \\
(40.48)\end{array}$ \\
\hline Splan_PtdGovernador & $\begin{array}{l}-54.30 \\
(60.23)\end{array}$ & $\begin{array}{l}-48.89 \\
(63.86)\end{array}$ & $\begin{array}{l}-16.73 \\
(37.38)\end{array}$ & $\begin{array}{l}-15.88 \\
(39.78)\end{array}$ \\
\hline Splan_Esq & $\begin{array}{c}72.39 \\
(63.99)\end{array}$ & $\begin{array}{c}80.29 \\
(66.55)\end{array}$ & $\begin{array}{c}42.80 \\
(40.82)\end{array}$ & $\begin{array}{c}38.38 \\
(45.06)\end{array}$ \\
\hline GovEsquerda & & $\begin{array}{c}20.81 \\
(43.21)\end{array}$ & & $\begin{array}{c}14.55 \\
(40.48)\end{array}$ \\
\hline Constante & $\begin{array}{c}1,223^{* *} \\
(539.2)\end{array}$ & $\begin{array}{c}1,340 \\
(979.1)\end{array}$ & $\begin{array}{c}1,313^{* *} \\
(527.1)\end{array}$ & $\begin{array}{c}334.8 \\
(785.6)\end{array}$ \\
\hline Estimador & OLS & OLS & GLS & GLS \\
\hline Controles Político-Institucionais & Não & Sim & Não & Sim \\
\hline Observações & 591 & 540 & 591 & 540 \\
\hline
\end{tabular}

Tabela 25 - Regressão das características dos Secretários do Planejamento, inclusive binárias de ideologia do Secretário e do Governador, sobre o Erro de Previsão 